\title{
Hydro-economic Models: Concepts, Design, Applications, and Future Prospects
}

\author{
Julien J. Harou ${ }^{1}$, Manuel Pulido-Velazquez ${ }^{2}$, David E. Rosenberg ${ }^{3}$, Josué Medellin-
} Azuara $^{4}$, Jay R. Lund ${ }^{4}$, Richard E. Howitt ${ }^{5}$

\begin{abstract}
Future water management will shift from building new water supply systems to better operating existing ones. Given these goals, hydro-economic models that show the dynamic variation of water values in time and space will be increasingly used to suggest ways to address water scarcity and reduce water conflicts. Hydro-economic models represent spatially distributed water resource systems, infrastructure, management options and economic values in an integrated manner. In these tools water allocations and management are either driven by the economic value of water or evaluated by that measure to provide policy insights and reveal opportunities for better management. A central concept is that water demands are not fixed requirements but rather functions where quantities of water use at different times have varying total and marginal economic values. This paper reviews techniques to characterize the economic value of water use and include such values in mathematical models. We identify the key steps in model design and diverse problems, formulations, levels of integration, spatial and temporal scales, and solution techniques addressed and used by over 60 hydro-economic modeling efforts dating back 45-years from all over the world. We list current limitations of the approach, suggest directions for future work, and recommend ways to improve policy relevance so promising management strategies and policy insights identified by hydro-economic models can be better employed.
\end{abstract}

${ }^{1}$ Environment Institute and Department of Civil, Environmental and Geomatic Engineering, University College London, London, UK

${ }^{2}$ Hydraulic and Environmental Engineering Department, Technical University of Valencia (Univ. Politecnica de Valencia) Cami de Vera, s/n. 46022, Valencia, Spain

${ }^{3}$ Department of Civil and Environmental Engineering, Utah Water Research

Laboratory, Utah State University, UT, USA

${ }^{4}$ Department of Civil and Environmental Engineering, University of California, Davis, CA, USA

${ }^{5}$ Department of Agricultural and Resource Economics, University of California, Davis, CA, USA 


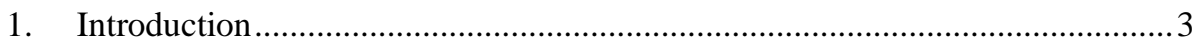

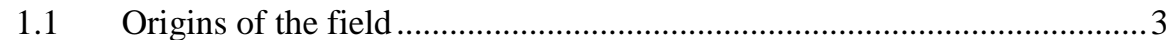

$1.2 \quad$ Hydroeconomic models: features and purpose ..................................... 4

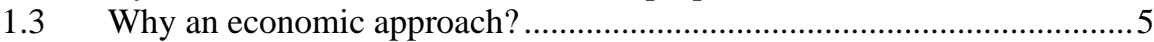

2. Economic concepts for water valuation and allocation ..................................6

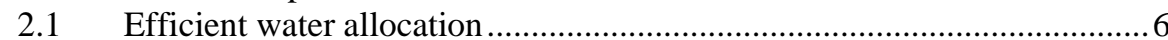

2.2 Determining economic value and production costs of water....................8

2.2.1 Urban water demands .......................................................... 9

2.2.2 Agricultural water demands ........................................................... 9

2.2.3 Hydropower and Industrial water demands ...................................... 10

2.2.4 Environmental and recreational water demands ............................... 10

2.2.5 Production costs ................................................................... 11

3. Hydroeconomic model design and implementation ..................................... 11

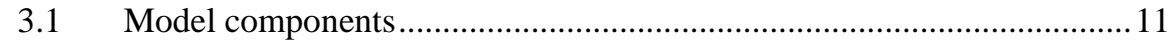

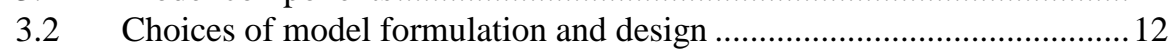

3.2.1 Simulation or optimization? ................................................... 12

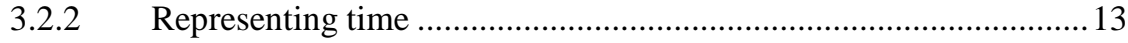

3.2.3 Submodel integration ................................................................. 14

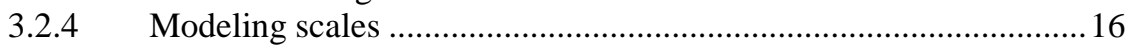

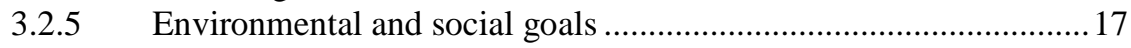

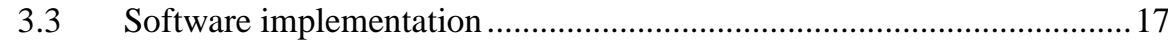

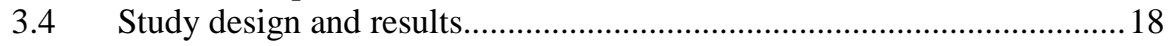

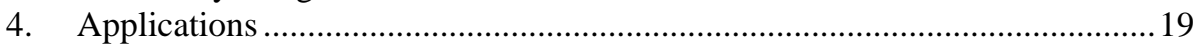

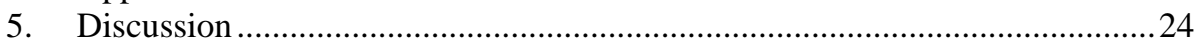

5.1 Policy and institutional implications.................................................24

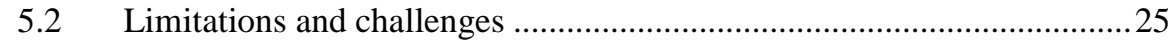

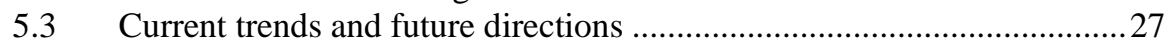

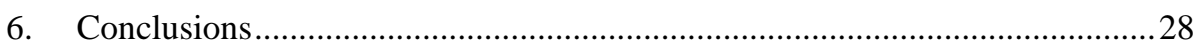




\section{Introduction}

Recent decades have seen widespread use of systems analysis to help manage water resources. Systems analysis applied to water resources uses simulation and optimization models to explore the benefits of managing environmental systems as interdependent integrated units. Since the earliest applications of systems analysis to water resources, economic objectives and constraints have often been used (Loucks et al., 1981; Maass et al., 1962).

\subsection{Origins of the field}

Economics and engineering are kindred disciplines which have frequently exchanged fundamental ideas over their long history (Lund et al., 2006). Modern engineering and economics share common ancestors in the French engineering schools of the 1800’s (Hayek, 1950; Langins, 2004). A striking example is the fundamental economic concept of consumer surplus (section 2.1) introduced by the French engineer Jules Dupuit (Dupuit, 1844; Ekelund and Hebert, 1999). This contribution and others were part of an effort to design civil infrastructure that would best serve society. Dupuit recognized the need to consider construction and operating costs; as well as the economic benefits of proposed public hydraulic works and operating schemes.

Water engineers continued to incorporate economic principles throughout the $19^{\text {th }}$ and $20^{\text {th }}$ centuries, increasingly in a system's analysis context. Often, optimization provided the mathematical link between economics and engineering. Economic engineering in the water field emphasizes the use of economic principles to support decision making, flexible and integrated management, benefit valuation, plan design, alternative evaluation, finance, and institutional design (Braden, 2000; Griffin, 1998; Lund et al., 2006). One manifestation of this mutually beneficial collaboration was the development of hydro-economic models.

Hydro-economic modeling can be traced to the 1960's and 70's in arid regions such as Israel and the south-western United States. Early use of economic water demand curves to optimize a water resources systems were made by Jacob Bear, Oded Levin and colleagues (1966; 1967; 1970; 1964), Rogers and Smith (1970), and Gisser and Mercado (1972; 1973). Bear et al. established the conceptual framework (Gisser and Mercado, 1973; Noel et al., 1980) for regional-scale integrated water management models where water is allocated and managed by maximizing net benefits derived from economic water demand curves. Since then researchers have used different names to refer to applications and extensions of this hydrologic engineering economic water modeling approach including: hydrologic-economic (Gisser and Mercado, 1972), hydroeconomic (Noel and Howitt, 1982), economic-hydrologicagronomic (Lefkoff and Gorelick, 1990b), institutional (Booker and Young, 1994), integrated hydrologic-economic-institutional (Booker, 1995), integrated river basin optimization (Ward and Lynch, 1996), efficient allocation (Diaz and Brown, 1997), integrated economic-hydrologic (McKinney et al., 1999; Rosegrant et al., 2000), economic-engineering (Draper et al., 2003; Lund et al., 2006; Newlin et al., 2002), 
integrated hydrologic-agronomic-economic (Cai et al., 2003a), demand and supply (Griffin, 2006), integrated hydrologic-economic (Cai et al., 2003a; Pulido-Velazquez et al., 2006), holistic water resources-economic (Cai and Wang, 2006; Cai, 2008), integrated hydrodynamic-economic (Jonkman et al., 2008), and integrated ecologicaleconomic (Volk et al., 2008). This review will use 'hydroeconomic' (Noel and Howitt, 1982) for brevity.

\subsection{Hydroeconomic models: features and purpose}

Hydroeconomic models represent regional scale hydrologic, engineering, environmental and economic aspects of water resources systems within a coherent framework. The idea is to operationalize economic concepts by including them the heart of water resource management models. These models have emerged as a privileged tool for conducting integrated water resources management (IWRM) (Cardwell et al., 2006; Global Water Partnership, 2000; Mariño and Simonovic, 2001). Hydroeconomic models are solution-oriented tools for discovering new strategies to advance efficiency and transparency in water use. The goal is to look at a system in a fresh way to discover promising water management ideas and policy insights. Recent hydroeconomic modeling research has been described by McKinney et al. (1999), Jakeman and Letcher (2003), Lund et al (2006), Heinz et al., (2007), Cai (2008), Pulido-Velazquez et al. (in press) and Brouwer and Hofkes (2008).

Engineers traditionally evaluate costs of building, operating and maintaining water supply, conveyance, storage, sewerage, drainage, and waste-water reuse infrastructure and estimate water requirements. In non-economic system models, water demands are commonly represented by fixed water "requirements" or delivery targets. The profession has often relied on a static view of water demands which can lead to overdesign of infrastructure, waste, and slow adaptation to new conditions. In a mature water economy (Randall, 1981) with rapidly rising incremental costs of new supplies (aquifers already heavily exploited, best dam locations taken and other rivers protected) and increased conflicts among water users, a wider view is needed to face water scarcity problems. Economics helps water managers move from a static view of water demand, defined through water rights, priorities and projections of population growth and agricultural and industrial water requirements to a view of demand related to the economic concept of value. Water value changes with the quantity and type of use. Monetizing all water uses allows for an even-handed comparison among uses. This monetization converts a complex multiobjective optimization problem into a simpler single-objective problem.

Hydroeconomic models differ from other economic or engineering models. Water allocation is driven or evaluated by the economic values it generates, often with transfers, buying, and selling among users. Unlike economic models involving water such as dynamic optimization of groundwater stocks, economy-wide general equilibrium models, input-output analysis, cost-benefit analysis, etc., the previously listed variations of the term "hydroeconomic" have been used for models representing all major spatially distributed hydrologic and engineering parts of the system. Representations include water balance components such as river flows, evaporation from surface water bodies, natural groundwater recharge and discharge, and return flows. Relevant water supply infrastructure and operations may include canals, 
reservoirs, desalination plants, water and waste-water treatment plants, groundwater or pipeline pumping stations, artificial recharge basins and other groundwater banking infrastructure. These hydrologic and engineering features are included in a node-link mathematical network, where economic demands have locations (nodes) and costs (or benefits) are incurred on links. The network accommodates both physical and economic spatially distributed systems, and is the integrating element of hydroeconomic models.

Economy-wide economic models, such as general equilibrium or input-output models differ from most hydroeconomic models by representing how water resource policies or shocks affect the entire economic system, rather than focusing only on how economics affects water resource management. Typically these models do not consider spatially distributed management systems (e.g. Mukherjee, 1996) and so are not described here. Recently however, Jonkman et al. (2008) estimate both direct (flood damages) and indirect (economy-wide) costs of a major flood in the Netherlands by combining a hydrodynamic model with an input-output economic damange model. Including economic water demands in addition to costs/benefits distinguishes hydroeconomic models from purely engineering models that maximize profit (e.g. hydropower operation) or minimize capital and/or operating costs.

\subsection{Why an economic approach?}

Due to the life-sustaining qualities of water for humans and the environment, some commentators object to the use of economics to manage water. However, unrestricted human access to clean water for basic needs and sufficient environmental and public use allocation are compatible with and encouraged by an economic approach to water management (Young, 2005b, p. 8).

| -Because basic human water needs are small compared to the amounts used for other needs and by other sectors, all management of water should not be designed solely for basic human needs. From an economic stand-point, managing any resource efficiently ("Pareto efficiency") occurs when a water allocation can provide no further gains in production or satisfaction without simultaneously creating an equal loss. Griffin (2006, p. 50) further distinguishes between neutral (Pareto front) and aggregate efficiency (maximize net benefits irrespective of distribution) to enable social preferences such as equity to be explicitly incorporated in the efficiency objective. Economics offers methods to evaluate and foster both equity and efficiency.

Besides health-sustaining human consumption and some noneconomic values, water has value as: a commodity and input into various instream and offstream production processes, as a diluter and transporter of waste, recreational space, and ecological habitat (Young, 2005b, p. 6). Representing these interests using a common monetary unit whenever possible establishes a framework for evaluating the tradeoffs and synergies among competing water uses.

Use of economic tools is not tantamount to advocating a general adoption of markets to allocate all resources; nor does it assume privatization. Constraints on allocations and flows are readily included to represent political and cultural norms.

Environmental demands can be valued or included as constraints if their economic value proves too difficult or controversial to estimate. Further, hydroeconomic 
models are restricted in their ability to represent some practical aspects of markets such as transaction costs and agent behavior (Griffin, 2006).

According to the 1992 UN Dublin statement, "Managing water as an economic good is an important way of achieving efficient and equitable use, and of encouraging conservation and protection of water resources” (U.N., 1992). Under conditions of water scarcity an economic focus helps identify efficient water allocations and reduce wasteful practices. Water is typically allocated according to historical, institutional, political, legal, and social traditions and conditions. This division of water resources can be slow to adapt to environmental or water demand changes. Economic techniques help to allocate scarce resources and identify appropriate trade-offs between resource uses that reflect the values and choices of society.

\section{Economic concepts for water valuation and allocation}

Economics applied to water management has a long and distinguished history. Some basic concepts integral to understanding hydroeconomic models are described below. Several recent introductory textbooks provide accessible but in depth coverage of the economics of water resources (Gibbons (1986), Tsur et al. (2004), Young (2005b), (Fisher et al., 2005), and Griffin (2006)).

\subsection{Efficient water allocation}

A key concept for efficient water allocation is that water use values and costs vary with quantities rather than being fixed. Water is more valuable in a drought than in a wet period, and supply costs increase disproportionally when doubling output if all major water sources are already exploited. Many traditional water planning practices assume fixed water use targets and operations, independent of prices and costs.

A demand curve (Figure 1) for water presents consumer's willingness to pay for varying quantities of water. The y-axis is unit price or marginal willingness to pay, the $x$-axis is the quantity available. Note, that due to a quirk of economic history, water demands are, counterintuitively, defined as the quantity demanded (X axis) being a function of the price ( $\mathrm{Y}$ axis). A steeper demand curve implies water use is highly less responsive to price changes (high-low price-elasticity) and user's total value for water use is very sensitive to water availability. Demands curves are essential for economic analysis; section 2.2 discusses how they are estimated for various water uses. Figure 1 shows how the area under a demand curve quantifies market value (ABDE) and consumer surplus (BCD), the sum of which are the gross benefits from a water delivery. 


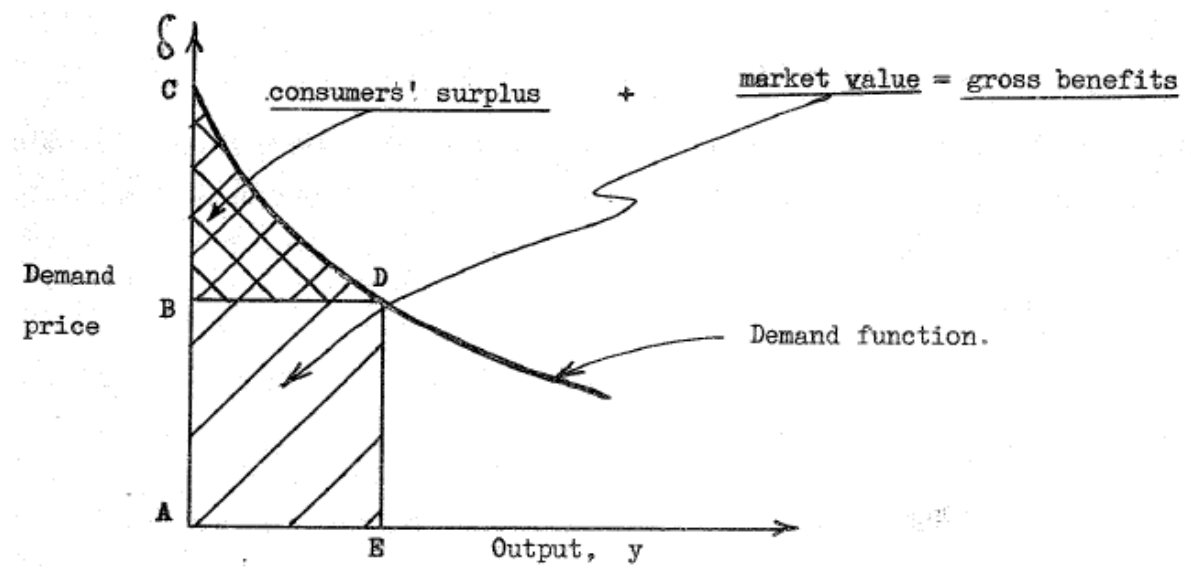

Figure 1: Demand function consisting of the price (willingness-to-pay) for water at different quantities. Note that for a small quantity of water ("Output", y), the price is high (C). (Bear et al., 1964). N.B. market value alternatively named producer surplus.

Integrating the demand curve quantifies the gross economic benefits derived from water allocation (see Figure 2(b)). In this way demand functions can be used to allocate water to sectors that use it most productively. The optimal efficient water allocation maximizes the aggregated net economic benefit (value) of water use in the system. The objective function can equivalently be formulated as a cost-minimization problem in which the costs modeled include benefits forgone (i.e. scarcity costs) and operating costs (e.g. Draper et al., 2003).

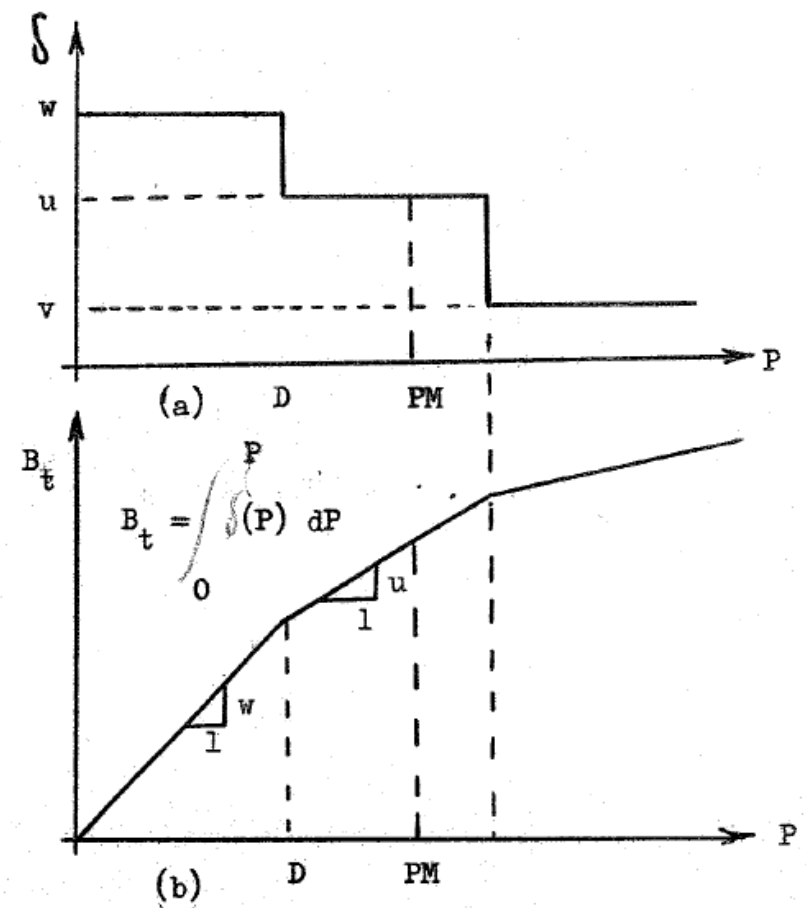

Figure 2: Describes the relationship between the demand curve (a) and gross economic benefits (b). Note that the demand "curve" in (a) is a step function made from two data points. When 
this step function is integrated, (b) is piece-wise linar. (Bear et al., 1964). If the demand curve in figure 1 were integrated, the economic benefit function would be smooth. In both cases benefits exhibit dimishing marginal returns (rate of benefits decreases as water quantity increases).

Maximizing net benefits is equivalent to reallocating water until marginal net benefits are equal among all uses. The concept of marginality is central in economics to express the benefit or cost of 1 additional resource unit ("at the margin"). The microeconomic equimarginal principle states that in an optimal allocation among sectors, each sector derives the same utility from the last unit of resource allocated. In practice the equimarginal principal often does not hold at all time periods and locations within the hydroeconomic network because of non-economic constraints (e.g. hydrologic, engineering, institutional, ...) (Cai, 2008) and the limited ability to respond to dynamic conditions.

\subsection{Determining economic value and production costs of water}

The prices for water in well-functioning water markets would offer an opportunity to directly observe water's economic value. Because markets are usually absent or inefficient, it is often necessary to estimate economic value of water using alternative approaches (recently reviewed by Young, 2005b). Valuation approaches and results depend on which specific water services are being valued, as well as where and why the valuation exercise is being conducted. Valuation of water can occur from a supply or demand perspective, resulting in a supply curve or a demand curve for water. For many water managers, the economic value of water evokes the capital (investment) and operating costs of supplying water that result in a supply cost curve. These tangible costs are typically calculated by engineering economists or accountants and are often simplified as being constant with respect to amount supplied (Griffin, 2006, chapter 10).

Economics contributes most to valuation from the water demand perspective where simpler methods are unusable. Gibbons (1986) provides a good primer. Valuation is done differently depending on whether water is considered an intermediate or a final good. When water is an input to a production process, such as in irrigation, hydropower generation and commercial or industrial uses, water demand is derived from the demand for the final output and the production function. In these cases water is an "intermediate good" and its demand is referred to as a derived demand. Residential or recreational water use are final demands. These differences have important implications for valuation method selection, since different economic theories (of consumer's and producer's demands) are applicable to each case (Hanemann, 1998). When water is a final good, demand is influenced by consumer preferences. Water provides direct utility to the consumers who are willing to pay a specific amount of money for it. For intermediate goods (derived demand), water demand will be influenced by the technology producing the final goods and demand for the final output. In this case, estimating the economic value of water is equivalent to isolating the marginal contribution of water to the total output value (residual value).

Two broad approaches (Kindler and Russell, 1984) are available to model water demand: inductive and deductive valuation techniques. Inductive techniques rely on 
econometric or statistical analysis of observed data to estimate price-response. This empirically-based technique is considered a 'positive' form of analysis. Deductive techniques usually use mathematical programming (optimization), although general equilibrium models and residual value methods also fall in this category (see Tsur et al., 2004). Assuming optimal actions subject to economic and physical constraints is a normative approach which has prompted more "positive" variations (e.g. Howitt, 1995). In general econometric methods are data-intensive while optimization models are computationally-intensive.

\subsubsection{Urban water demands}

Since Howe and Linaweaver (1967) econometric approaches to estimate price response and marginal benefits for the consumer dominate the literature (Arbués, 2003). Most use cross-sectional data, but also time series and panel data. The discussions have focused on which variables to include in the model in addition to water quantity and price, the best functional forms for statistical estimation, data, and magnitudes of the estimated price and income elasticities (Espey et al., 1997; Martin and Thomas, 1986). The main challenge to econometric estimations of water priceelasticity is the simultaneity problem posed by block-rate schedules, the level of dissaggregation, dataset size, and the price specification (Young, 2005a). Typical econometric applications include specification of a marginal price variable, a TaylorNordin difference variable, demographics, and climate data as regressors for water use (e.g. Griffin and Chang, 1991). Estimates of price-elasticity of water demand range from zero to almost two in absolute value (Espey et al., 1997). Price elasticity is the percent change in consumption per percent change in price.

Several indirect methods have been also proposed to estimate economic costs of urban water scarcity based on optimization models that select the least-cost mix of residential water-saving techniques (Alcubilla and Lund, 2006; Lund, 1995) or through contingent valuation surveys of willingness to pay (WTP) to avoid shortages (Griffin and Mjelde, 2000). Given lack of data, an easy form to characterize the residential demand curve within hydro-economic models is the "point-expansion method". This method uses the data on observed price and water demanded at that price, a seasonal estimate of the long-run price-elasticity of that demand, then calibrates the parameters for a two parameter functional form by solving the resulting two identities. Constant price-elasticity forms are common in water management models that include the computation of consumer surplus (Griffin, 1990; Jenkins et al., 2003).

\subsubsection{Agricultural water demands}

Irrigation is by far the largest user of water. Literature abounds on how to derive agriculture water demand curves and price-elasticities (Tsur et al., 2004; Young, 2005b). Average and median values for price-elasticities for irrigation water fall in the inelastic range (Scheierling et al., 2006). Irrigation water demands are derived demands, since water is a production process input. Information on agricultural productivity can be used to construct crop-water production functions, from which the marginal physical product (first partial derivative of the production function with respect to the water input) can be derived for different water quantities. Finally, the marginal value (i.e. the demand curve) can be obtained from multiplying marginal physical productivities by crop prices. 
Crop-water production functions represent the relation between water use and crop output, for particular agrobiologic and climatic conditions. This relation can be derived directly from controlled field experiments, from econometric methods (Moore et al., 1994), or by agronomic simulation models that yield the response of the crops to water applied under specific agronomic and climatic conditions (Dinar and Letey, 1996). Optimization models can be an alternative to data-intensive econometric methods. Howitt (1995) combines regional equilibrium models and positive mathematical programming (PMP) to calibrate flexible crop production functions.

Irrigation water demands depend on farmers decisions' on crop mix and timing, water application, and irrigation technology. Many factors affect farmer's decision on crop mix (crop selling price, input costs, water availability and water price, agro-climatic characteristics, and risk and management effort involved). An extensive literature on mathematical programming models tries to reproduce farmer's decisions at the farm or irrigation district level. Most maximize profit or gross revenue. PMP models calibrate these optimization models to reproduce observed farmer decisions.

Irrigation water demands are usually represented in hydro-economic models using piece-wise linear or quadratic equations, exogenously generated, relating water application to economic benefits. In some cases, complex crop yield functions are explicitly included in the model (Cai et al., 2003b).

\subsubsection{Hydropower and Industrial water demands}

The benefits of hydropower production are often defined using the alternative cost technique, calculating the cost savings of hydropower compared with the next less expensive energy production alternative (Booker and Young, 1994; Gibbons, 1986). Benefit functions also can be derived from the quantity of energy produced and its energy market price. The energy produced depends on the powerplant discharge, the hydraulic head and the efficiency of the turbine-generator group. Hydraulic head is often represented as a linear function of reservoir storage (Cai et al., 2003a; Diaz et al., 2000).

As with commercial urban uses, elasticity of demand for industrial uses varies among types of industries (reviewed by Renzetti, 2002). Jenkins et al. (2001; 2003) characterize the industrial demand using a linear production loss function defined by the current consumption and data from a survey on the economic value of production lost if water deliveries were cut back by 30\% (CUWA, 1991).

\subsubsection{Environmental and recreational water demands}

Instream values for recreation and wildlife can be comparable to more traditional economic use values (Colby, 1990). Approaches for quantifying benefits of environmental water uses either infer WTP from observations of actual expenditure choices of the consumers (eg., travel cost method or hedonic pricing) or use surveys to directly ask the consumers about the values placed on changes in environmental services (contingent valuation) (Freeman, 2003; Young, 2005b). Benefit transfer approaches adapt results from studies in other sites (Brouwer, 2000). Despite the advances in methods and applications, environmental valuation is still an "imperfect art", subject to interpretation and debate (Braden, 2000; Shabman and Stephenson, 2000). Finally, shadow values on minimum flow constraints in hydroeconomic 
models provide the opportunity cost of environmental water, an indirect form of supply-side valuation (Medellin-Azuara et al., 2007).

\subsubsection{Production costs}

Water production costs include variable costs for pumping, treatment, and water quality improvement as well as capital and fixed costs for infrastructure and operations. Most hydroeconomic models are designed for management, and so they include only variable operating costs of existing infrastructure. For linear and nonlinear programming, variable costs must be convex (as they often are in practice due to decreasing returns to scale) to guarantee identifying the globally optimal solution.

For planning the capacity expansion of a system, fixed and capital costs should also be considered. However, fixed and capital costs are often non-convex due to the decreasing marginal costs that result from including fixed costs of facilities. This inhibits use of linear and non-linear programming, which is why fixed and capital costs are often ignored. There are alternative ways to include these costs. First, capacity expansion decisions can be considered as a side calculation outside the optimization process (comparing capital costs to benefits from separate optimization runs, one with and one without the infrastructure in place) (Fisher et al., 2005). Alternatively, capital costs are annualized (using the discount rate and estimated project lifetime) and then added to the operating costs. Third, capacity expansions are included as separate linear, integer, or binary decisions with additional constraints added to ensure operational decisions within existing and expanded capacity limits. Non-convex costs (for minimization problems, or non-concave costs for maximization problems) require using dynamic programming or heuristic search techniques to identify an optimal or nearly optimal solution.

\section{Hydroeconomic model design and implementation}

Many choices face the modeler when designing the mathematical formulation and choosing a solution algorithm. General rules and good practices of environmental modeling apply here as well (Jakeman et al., 2006). An essential feature is to design a model capable of answering questions and providing insights for resource managers, stakeholders and policy makers. Model design affects data requirements, available solution methods, and the types of results obtainable.

\subsection{Model components}

Most hydroeconomic models share basic components including hydrologic flows, water management infrastructure, economic water demands, operating costs, and operating rules. Since Maass et al. (1962), water resource systems have been modeled as networks of storage and junction nodes joined by conveyance links representing river reaches, canals, pipelines, etc. Water demands and consumption, and other features where water incurs a cost or benefit also are represented as nodes. The 
network format is straightforward, efficient and parsimonious for both simulation and optimization models. Boundary conditions in the form of inflows, outflows or other fixed flows can occur anywhere in the network.

Hydrologic flows entering and leaving the modeled domain and relevant internal inflows must be estimated. These include external surface or subsurface inflows and local precipitation-driven fluxes such as runoff and aquifer recharge. For operating purposes short-term forecasts of inflows based on operational weather predictions and current hydrologic conditions can be used. External system inflow data may come from historical flow gage records or synthetic time series generated by stochastic hydrology models. Alternative hydrologic scenarios, for example from downscaled global circulation models representing climate changes, may also be used. When historical data do not exist, calibrated hydrologic models can fill the gap. Hydrologic models are the main source for ungaged flows such as groundwater recharge, evaporation and local runoff.

Water management infrastructure consists of natural and built facilities for storing, conveying, treating, and using water such as river reaches, canals, pipelines, reservoirs, aquifers, pumps, powerhouses, treatment plants, and water demand intake locations. Minimum and maximum capacities and operating costs are specified for each element. Using data and network topology from existing models is a quick and credible way to build a hydroeconomic model. Simulation models calibrated and maintained by water management institutions are an ideal foundation for more abstract management models.

Economic water demands can be represented by functions providing gross economic benefits generated during a particular model time-step (Bear et al., 1964). If the model's objective is cost minimization, water scarcity costs incurred by lower deliveries can be represented by penalty functions (Newlin et al., 2002).

Environmental water uses may be alternatively represented with operating rules or constraints, where an objective function valuation is unavailable.

Operating costs include pumping, treatment, artificial recharge and other costs to move water between network nodes. They also can include negative costs (benefits) from hydropower generation. Water quality costs to urban users can be represented as operating costs, so they could be assessed and varied depending on the source of water delivered to each urban area, where incoming water quality varied primarily with source (Draper et al., 2003).

\subsection{Choices of model formulation and design}

Table 1 lists several model design choices and options hydroeconomic modelers must make to built a model. Further discussion on some of these choices follows.

\subsubsection{Simulation or optimization?}

Simulation and optimization answer different questions ('what if' and 'what is best' respectively) and can be used separately or together. Models that simulate decisions on a time-step by time-step basis can more realistically represent complex systems with nonlinear physical or institutional processes. Models focusing on detailed local 
decisions (e.g. farm level) often find simulation useful (Bredehoeft and Young, 1970; Brown and Rogers, 2006; Brown et al., 1990; De Ridder and Erez, 1977; Letcher et al., 2004; Marques et al., 2006; O'mara and Duloy, 1984; Young and Bredehoeft, 1972). Economic evaluation of simulated alternatives can provide insights on benefits and inefficiencies of design or management policy without driving water allocation and operations.

Optimization formulates problems using a mathematically stated objective subject to equations that represent physical and management constraints of the system. Multiperiod optimization links more than one time period in a single model. This helps capture the trade-offs of resource allocation over time such as storage in reservoirs and aquifers but may quickly yield large-models with non-linearity and perfect foresight of inflows. Optimization objective functions typically maximize net benefits (gross benefits derived from water use minus costs) or similarly minimize costs such as water scarcity costs, capital costs of investments, and operating costs. Optimization models can be solved analytically, with mathematical programming, dynamic optimization, or heuristic (global) search techniques such as evolutionary algorithms (give citations) or combinations of the above.

Because optimization's relevance in economic theory, hydro-economic models commonly use optimization computation engines regardless of whether they are built for simulation or optimization. When optimization is used to simulate (e.g. Draper et al., 2004; Labadie and Baldo, 2000; Marques et al., 2006; Reynaud and Leenhardt, 2008), each time-period is a separate optimization problem, with results at $t-1$ serving as boundary conditions for the model during period $t$. Simulation models can reproduce actual operating rules without benefiting from the perfect hydrologic foresight of multi-period optimization. For example, simulated reservoir releases are based on existing storage without anticipation of future inflows. Operating rules codify operational, legal and institutional regulations. They allow simulation models to replicate water allocation decisions in accordance with existing water management practices. Optimization models follow an objective rather than a set of rules that are not directly implementable, such as "maximizing regional net benefits". The purpose of deliberately simplifying or partially by-passing existing operating rules is to better explore the physical and economic potential of the system in order to propose policy insights and improvements. Simulation and optimization perform well together, using optimization to identify promising solution strategies and simulation models to test and refine these in more detail (Loucks et al., 1981).

\subsubsection{Representing time}

Deterministic models consider a single-set of fixed boundary conditions (e.g. flows and demands) and results. Deterministic models become probabilistic when run many times with different inputs and report results spanning a broad range of conditions (e.g. Monte-Carlo simulation, implicit-stochastic optimization) (Labadie, 2004).

Stochastic models explicitly consider the probabilistic nature of model inputs and parameters. Results take the form of probability distributions or processes rather than single numbers. Explicitly stochastic models are more common in pure engineering or pure economic models. Hydroeconomic models tend to implement variations of deterministic optimization where results are time-series of optimal allocation operations (e.g. storages and flows). 
If discounting is used to account for opportunity costs (the 'time-value of money'), a discount factor, $(1+i)^{-t}$ where $i$ is a discount rate, multiplies future benefits and costs of the objective function (evaluation function in simulation). Models that maximize present value of net benefits or net annualized benefits are commonly solved using linear or nonlinear mathematical programming (optimization). Dynamic optimization models using dynamic programming or optimal control consider inter-temporal substitution of resources rather than only present value (Conrad and Clark, 1987). If no economic consideration is explicitly given to time in the form of an equation of motion for the state variables, the model is referred to as static.

\subsubsection{Submodel integration}

Integration refers to how different submodels interact and the breadth of processes and decisions represented together. Holistic models endogenously (internally) calculate all inputs and outputs within a single model. A modular design connects independent submodels, without having them interacting within a single program. Braat and Lierop (1987) describe these respectively as holistic or compartment approaches, a terminology adopted by Cai (2008; 2003a) and Brouwer and Hofkes (2008). The main question is whether to solve the economic model endogenously within the water management model or to estimate water demands with an external economic model. The advantages of modularity include increased probability of convergence on an optimal solution, the ability to go into more detail in each subfield, and the ability to be independently updated and developed. Holistic models can more effectively represent causal relationships and interdependencies. Scenario-based studies such as climate change impact studies, are easier to execute with holistic models since they don't require representing the changed policies or conditions separately for each submodel. An example of a modular approach is Draper et al. (2003) where economic scarcity cost curves are determined by a exogenous economic model (Howitt et al., 2001). A holistic approach is presented by Cai et al. (2003a) where water demand curves are estimated endogenously. However, few models are fully 'holistic'; a seemingly holistic hydroeconomic model that does not represent rainfall-runoff processes would be considered modular in the context of a climate change impact study. Economy-wide economic models, such as general equilibrium or input-output models that represent spatial hydrology (e.g. Jonkman et al., 2008), are also holistic hydroeconomic models. They have wider breath, including how water resource policies or shocks affect the entire economic system, rather than focusing only on how economics effects water resource management.

Whether in a single or in separate models, the question remains of which model components to include and at what scale. A wide range of both hydrologic and engineered water supply processes and options can be represented. More or less detailed surface water, groundwater flow and stream-aquifer models can be embedded, drastically affecting run times and the scale at which management inferences can be made (Harou and Lund, in press-b). Water quality is rarely explicitly modeled in hydroeconomic models because of the added complexity and computational cost and the difficulty of quantitatively assessing economic effects; a recent exception is Volk et al. (2008). Constraints or additional costs for some water sources are used to implicitly represent water quality. Besides water resource and economic components, other submodels that may be relevant in a given context include agronomic and ecological submodels. 
Table 1: Some design choices, options, and implications for building a hydroeconomic model.

\begin{tabular}{|c|c|c|c|}
\hline $\begin{array}{l}\text { Choice and } \\
\text { Options }\end{array}$ & Summary & Advantages & Limitations \\
\hline \multicolumn{4}{|c|}{ Question to Answer } \\
\hline _Simulation & $\begin{array}{l}\text { Time-marching, rule- } \\
\text { based algorithms; } \\
\text { Answers question: } \\
\text { "what if?” }\end{array}$ & $\begin{array}{l}\text { Conceptually simple; } \\
\text { existing simulation } \\
\text { models can be used, } \\
\text { reproduces complexity } \\
\text { and rules of real } \\
\text { systems }\end{array}$ & $\begin{array}{l}\text { Model only investigates } \\
\text { simulated scenarios, } \\
\text { requires trial and error to } \\
\text { search for the best } \\
\text { solution over wide } \\
\text { feasibility region }\end{array}$ \\
\hline Optimization & $\begin{array}{l}\text { Maximizes/minimizes } \\
\text { an objective subject to } \\
\text { constraints*; } \\
\text { Answers question: } \\
\text { "what's best?" }\end{array}$ & $\begin{array}{l}\text { Optimal solutions can } \\
\text { recommend system } \\
\text { improvements; reveals } \\
\text { what areas of decision } \\
\text { space promising for } \\
\text { detailed simulation }\end{array}$ & $\begin{array}{l}\text { Economic objectives } \\
\text { require economic } \\
\text { valuation of water uses; } \\
\text { ideal solutions often } \\
\text { assume perfect } \\
\text { knowledge, central } \\
\text { planning or complete } \\
\text { institutional flexibility }\end{array}$ \\
\hline \multicolumn{4}{|c|}{ Representing time } \\
\hline $\begin{array}{l}\text { Deterministic } \\
\text { time-series }\end{array}$ & $\begin{array}{l}\text { Model inputs and } \\
\text { decision variables are } \\
\text { time-series, historical or } \\
\text { synthetically generated }\end{array}$ & $\begin{array}{l}\text { Conceptually simple: } \\
\text { easy to compare with } \\
\text { time series of } \\
\text { historical data or } \\
\text { simulated results }\end{array}$ & $\begin{array}{l}\text { Inputs may not represent } \\
\text { future conditions; } \\
\text { limited representation of } \\
\text { hydrologic uncertainty } \\
\text { (system performance } \\
\text { obtained just for a single } \\
\text { sequence of events) }\end{array}$ \\
\hline $\begin{array}{l}\text { Stochastic } \\
\text { and multi- } \\
\text { stage } \\
\text { stochastic }\end{array}$ & $\begin{array}{l}\text { Probability distributions } \\
\text { of model parameters or } \\
\text { inputs; use of multiple } \\
\text { input sequences ('Monte } \\
\text { Carlo' when } \\
\text { equiprobable sequences, } \\
\text { or 'ensemble approach' } \\
\text { if weighted. }\end{array}$ & $\begin{array}{l}\text { Accounts for } \\
\text { stochasticity inherent } \\
\text { in real systems }\end{array}$ & $\begin{array}{l}\text { Probability distributions } \\
\text { must be estimated, } \\
\text { synthetic time series } \\
\text { generated; presentation } \\
\text { of results more difficult; } \\
\text { difficulties reproducing } \\
\text { persistence (Hurst } \\
\text { phenomenon) and non- } \\
\text { stationarity of time } \\
\text { series }\end{array}$ \\
\hline $\begin{array}{l}\text { Dynamic } \\
\text { optimization }\end{array}$ & $\begin{array}{l}\text { Inter-temporal } \\
\text { substitution represented }\end{array}$ & $\begin{array}{l}\text { Considers the time } \\
\text { varying aspect of } \\
\text { value }\end{array}$ & $\begin{array}{l}\text { Requires optimal control } \\
\text { or dynamic } \\
\text { programming }\end{array}$ \\
\hline \multicolumn{4}{|c|}{ Submodel integreation } \\
\hline \multirow[t]{2}{*}{ Modular } & $\begin{array}{l}\text { Components of final } \\
\text { model developed and } \\
\text { run separately }\end{array}$ & $\begin{array}{l}\text { Easier to develop, } \\
\text { calibrate and solve } \\
\text { individual models }\end{array}$ & $\begin{array}{l}\text { Each model must be } \\
\text { updated and run } \\
\text { separately; difficult to } \\
\text { connect models with } \\
\text { different scales }\end{array}$ \\
\hline & $\begin{array}{l}\text { All components housed } \\
\text { in a single model }\end{array}$ & $\begin{array}{l}\text { Easier to represent } \\
\text { causal relationships } \\
\text { and interdependencies } \\
\text { and perform scenario } \\
\text { analyses }\end{array}$ & $\begin{array}{l}\text { Must solve all models at } \\
\text { once; increased } \\
\text { complexity of holistic } \\
\text { model requires simpler } \\
\text { model components. }\end{array}$ \\
\hline
\end{tabular}

* If optimized time-horizon is a single time period, the model can be considered a simulation model that uses an optimization computational engine. 


\subsubsection{Modeling scales}

Modeling scale is a critical subject encompassing spatial and temporal domain and discretization (Jakeman and Letcher, 2003). The domain describes the boundaries of the model. Spatial domains range from a single farm or household to groups of countries while the temporal domain is the model's time-horizon; often a year or more. Discretization describes the subdivision of the spatial and temporal modeled domains. The spatial domain is to be separated into subdomains (e.g. grid cells, subbasins) while the temporal domain is subdivided into time steps. Scale determines what issues and questions the model will be able to address.

The most common spatial domain considered in hydroeconomic modeling is regional although analysis can be useful from household to international scales. If the focus is on water demand management and conservation, household or utility-level models can help identify optimal investments at the household and water utility scales (Alcubilla and Lund, 2006; Rosenberg et al., 2007). Management at the utility scale can benefit from investigating pricing, infrastructure investment and operations and maintenance policies (Jenkins and Lund, 2000; Wilchfort and Lund, 1997). Using river basin boundaries to delimit model domain is especially appropriate when such boundaries also define the jurisdiction of water agencies. Hydroeconomic models have also been applied to transboundary river basin conflicts (e.g. Fisher et al., 2002).

Discretization relates how the spatio-temporal domain is subdivided. Spatially the model can be lumped (spatial variability), semi-distributed (e.g. using lumped subbasins or subregions) or distributed (mesh overlays domain). Most economic models of natural resource use are spatially lumped; with some element of spatial distribution of processes and variables being the trade-mark of most hydroeconomic models. Semi-distributed is the most flexible and commonly used spatial discretization. In a typical application the water resource system is represented by a node-link network, with flows routed between nodes using simplified hydrologic equations (ranging from mass balance equations to hydrologic routing schemes). Distributed hydraulic models (e.g. using a regular 1, 2 or 3-D mesh) are uncommon in hydroeconomic models as such detail is usually not relevant at the policy and planning levels. An exception is spatially discretized groundwater models, because of groundwater pumping costs and spatially dependent environmental effects (PulidoVelazquez et al., 2006; Schoups et al., 2006b).

The semi-distributed approach brings the challenge of linking hydrologic and water supply infrastructure to areas where economic water demand or production is homogenous enough to be modeled as a unit (Cai, 2008). The node-link structure is well-suited to link different scales; network connectivity can usually be represented concisely in a single connectivity matrix (Labadie, 2004). While choosing a water resource scale will strongly effect what equations are used to model water resources, economic formulations tend to vary less across different scales.

Temporal domains range from a few days for operational models to decades for planning applications. Few hydroeconomic models explicitly consider the stochastic nature of inflows because of the impractical computation burden. Temporal discretization depends on the management questions of concern. Models focusing on short-term operations (e.g. flood control, hydropower) use small time steps (daily or less) to model hydrologic and hydraulic processes such as flow routing. Maximizing 
net benefits from hydropower operations often requires a daily time step or smaller. Operations models only represent groundwater when stream-aquifer fluxes are significant. When flow through the surface water system is faster than model time step, flow routing in rivers is unnecessary and should be avoided. Models focusing on longer-term planning such as reservoir storage use weekly to annual time-steps and rarely require flow routing (except for flood operations). In this case, flows are instantaneous and modeled with a mass-conserving network. Here the focus is on long-term storage and allocation operations such as in conjunctive use of surface water and groundwater, drought management, or screening for infrastructure development.

\subsubsection{Environmental and social goals}

Another design choice is how to represent environmental or 'ecological' flows. Modelers can use environmental economic valuation techniques (section 2.2.4) or treat environmental requirements as low-flow constraints (e.g. Jenkins et al., 2004; Pulido-Velazquez et al., 2006). The latter approach is helpful when it is difficult or controversial to value environmental services. Other models use environmental and recreational economic value functions obtained using non-market valuation techniques, so that non-consumptive instream uses and consumptive uses compete for the allocation of water in the system (Diaz et al., 2000; Ward and Lynch, 1996).

Like ecological goals, social policies and political considerations can readily be included as constraints within hydroeconomic models (Fisher et al., 2002).

Hydroeconomic tools help evaluate the equity implications of different water policies since they estimate the redistribution of benefits and costs among affected parties (e.g. Draper et al., 2003). Evans et al. (2003) analyzed the trade-offs among the goals of efficiency, equity in water allocation and equity in income distribution for an agricultural watershed. Cai et al. (2002) distinguished between temporal and spatial equity. Ward and Pulido-Velazquez (in press-b) test a two-tiered water pricing system that sets a low price for basic needs, while charging full marginal cost for discretionary uses.

\subsection{Software implementation}

Many software options are available for running hydroeconomic models; these can be summarized into three overlapping categories: optimization modeling systems, generalized decision support software (DSS), and custom-software built for a specific solver. Optimization modeling systems integrate model data, formulation, solution and results definition. Examples of such systems include GAMS, Lingo, AMPL; all of which link model equations written in custom languages to commercial solvers implementing linear, integer or nonlinear optimization. These systems are flexibile, transparent, self-documenting, provide simple links between model formulation and solver solution, and therefore have seen early and widespread adoption by both economists and engineers for implementing hydroeconomic models. A related solution is to access solvers through spreadsheets (e.g. EXCEL).

Generalized decision support software containing hydroeconomic modeling components include AQUARIUS (Brown et al., 2002; Diaz and Brown, 1997), 
AQUATOOL (Andreu-Álvarez et al., 2005; Andreu et al., 1996), Pulido-Velazquez et al., in press) WAdss (Letcher, 2005), WSM DSS (Todini et al., 2006), AQUAPLAN (Tilmant et al., in press), and WaterWare (Cetinkaya et al., 2008). The Water Allocation DSS (WAdss) is an application of a generalized modeling framework, the Interactive Component Modelling System (ICMS) (Argent et al., 2006). Another approach to generalized software is to build customized software as an intermediary between a solver and a database containing data and model parameters as with CALVIN (Draper et al., 2003) and WAS (Fisher et al., 2002; Rosenberg, in press).

\subsection{Study design and results}

A typical hydroeconomic modeling study involves a base case representing current infrastructure and water management practices. Reproducing historical results is important for establishing model credibility. Further alternatives and scenarios may include new infrastructure, operating rules, institutional and policy changes, changes in demands or hydrologic conditions (e.g. climate change), or combinations of these. Users then compare and contrast results for the different alternative and scenarios.

Establishing a base case is related to model calibration, the process by which model input data, parameters, assumptions and process equations are tested and iteratively improved to better agree with observed results. Model calibration often is a lengthy process through which much modelers learn much about both the water system under consideration and about their model's assumptions, limitations and benefits (Draper et al., 2003). Partially automated calibration methods have been applied to optimization models (Cai and Wang, 2006; Howitt, 1998) based on the concept of PMP (Howitt, 1995).

Basic results of both simulation and multi-period deterministic optimization are overall economic performance and the time series of water system operations (e.g. reservoir releases, groundwater pumping, artificial recharge, etc.). For small systems, operation rule parameters can be solved for directly (Schoups et al., 2006a); for large systems they can be derived by statistically analyzing optimal operations (Lund and Ferreira, 1996). When optimization is used, marginal values (i.e. "value of one more unit”) of water and infrastructure are a significant result from hydroeconomic models. Shadow These marginal values (dual values, shadow values, Lagrange multipliers) are produced by mathematical programs when a constraint limits the optimal solution and indicate the change in the objective if the constraint were relaxed by one unit. Because hydroeconomic models are single-objective measured in monetary units, shadow values have direct economic significance. Hydroeconomic optimization models produce valuable information on marginal values of water, infrastructure and ecological flows. In a standard network formulation, shadow values on flow continuity constraint equations provide time series of the monetary value of adding one unit of flow at any model junction, shadow values on infrastructure constraints.

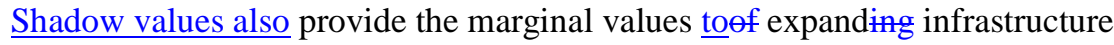
bottlenecks, and shadow alues on low flow constraints or reveal the opportunity cost society is-paysing for the ultimate to maintain low flow requirements unit(i.e. having itan instream-flow be $10 \mathrm{~m}^{3} / \mathrm{s}$-rather than $9 \underline{\mathrm{m}^{3} / \mathrm{s}}$ ). 
These are just some examples of generic output. In reality, the range of outputs matches the breath of the diversity of reasons to build hydroeconomic models. A representative set of applications is described in the next section.

\section{Applications}

Hydroeconomic modeling applications in the literature cover a range of water resources problems, locations, and innovations $\_$, summarized in Table 2). The $\pm \underline{T}$ able $\underline{2}$ divides the applications into 7 permeable groups, described briefly here.

Applications for instream uses include hydropower, navigation and recreation. Offstream uses are usually consumptive, e.g. irrigated agriculture or urban supply. To allocate water efficiently, instream flow values must be incorporated into the allocation process (Colby, 1990; Griffin and Hsu, 1993). However, environmental water uses, such as ecological minimum instream flows are usually not represented economically; no such applications were found. Endogenous agronomic models can be used to represent the effects of agricultural practices on water use and vice versa. Agricultural yield can be simulated given particular water applications, irrigation technology and water salinity levels.

Engineering infrastructure and capacity expansion are themes of engineering focused models that use economic criteria for evaluation. An advantage of optimization to analyze water supply infrastructure is that shadow values evaluate marginal value of capacity (Rogers and Smith, 1970).

When groundwater is managed conjunctively with the rest of the water resource system, hydroeconomic models can show the potential for groundwater banking (Harou and Lund, in press-a; Pulido-Velazquez et al., 2004). Models that represent groundwater pumping costs that vary with depth are nonlinear (quadratic) since water levels will depend on volume pumped. Distributed-parameter groundwater models add spatial information which enable local relevance of model results, rather than broad regional trends.

Many papers investigate the benefits of flexible allocation through various types of water markets. Water markets are always regulated by institutions that impose constraints to protect against environmental degradation or secondary economic effects (externalities). Modeling various constrained markets can helps identify more effective and beneficial arrangements for the regional economy.

Water management models that consider economic criteria tend to contradict theories about looming regional or global water conflicts. They provide a blue print for collaboration and adaptability that will help move from transboundary conflict to collaboration (Fisher et al., 2005).

Drought and climate change place special stresses on water systems. Hydroeconomic models may provide insights into flexible operations schemes that decrease negative affects of increased water scarcity or other changes. 
Land use management for floods and non-point source pollution from agriculture are fertile ground for a new generation of hydro-economic models built into spatial decision support systems (DSS) or geographical information systems (GIS).

Table 2: Selected hydroeconomic modeling applications grouped into categories. Many studies mentioned here could be placed under several application categories; one is chosen based on salient model features.

\begin{tabular}{|c|c|c|c|}
\hline Major problem(s) & Location & $\begin{array}{l}\text { Model Features and } \\
\text { Innovations }\end{array}$ & Citation(s) \\
\hline \multicolumn{4}{|c|}{ Instream and offstream intersectoral allocation and use } \\
\hline $\begin{array}{l}\text { Water scarcity, } \\
\text { inefficient allocation } \\
\text { of small flow } \\
\text { increases }\end{array}$ & $\begin{array}{l}\text { Hypothetical } \\
\text { basin, Western } \\
\text { USA }\end{array}$ & $\begin{array}{l}\text { Allocation to hydropower of } \\
\text { water obtained by vegetation } \\
\text { removal }\end{array}$ & $\begin{array}{l}\text { (Brown et al., } \\
\text { 1990; Diaz et al., } \\
\text { 1992) }\end{array}$ \\
\hline $\begin{array}{l}\text { Exploiting synergies } \\
\text { among non- } \\
\text { consumptive uses }\end{array}$ & $\begin{array}{l}\text { Rio Chama } \\
\text { Basin, New } \\
\text { Mexico }\end{array}$ & $\begin{array}{l}\text { Complementarities between } \\
\text { river recreation, lake } \\
\text { recreation, and hydropower }\end{array}$ & $\begin{array}{l}\text { (Ward and } \\
\text { Lynch, 1996; } \\
\text { Ward and Lynch, } \\
\text { 1997) }\end{array}$ \\
\hline $\begin{array}{l}\text { Preserving springs } \\
\text { for recreation and } \\
\text { ecological habitat }\end{array}$ & $\begin{array}{l}\text { Edwards } \\
\text { Aquifer, Texas, } \\
\text { USA }\end{array}$ & $\begin{array}{l}\text { Groundwater management for } \\
\text { ecological habitat protection, } \\
\text { water market investigated }\end{array}$ & $\begin{array}{l}\text { (McCarl et al., } \\
\text { 1999) }\end{array}$ \\
\hline $\begin{array}{l}\text { Trade-offs between } \\
\text { ecological and } \\
\text { economic objectives }\end{array}$ & $\begin{array}{l}\text { Border } \\
\text { Rivers region, } \\
\text { Queensland, } \\
\text { Australia }\end{array}$ & $\begin{array}{l}\text { Consequences of trade and } \\
\text { allocation water for } \\
\text { environmental use; minimizes } \\
\text { differences between actual } \\
\text { and natural flow regimes }\end{array}$ & (Tisdell, 2001) \\
\hline $\begin{array}{l}\text { Agricultural, urban } \\
\text { and environmental } \\
\text { uses }\end{array}$ & $\begin{array}{l}\text { Maipo basin, } \\
\text { Chile }\end{array}$ & $\begin{array}{l}\text { Return flows, considers } \\
\text { hydrologic and economic } \\
\text { efficiency }\end{array}$ & $\begin{array}{l}\text { (Cai, 2008; Cai } \\
\text { et al., 2003c; } \\
\text { Rosegrant et al., } \\
\text { 2000) }\end{array}$ \\
\hline $\begin{array}{l}\text { Over-allocated } \\
\text { surface and ground- } \\
\text { water supplies }\end{array}$ & $\begin{array}{l}\text { Namoi Basin, } \\
\text { Australia }\end{array}$ & $\begin{array}{l}\text { Trade-offs from water } \\
\text { allocation policies; integrated } \\
\text { assessment }\end{array}$ & $\begin{array}{l}\text { (Letcher et al., } \\
\text { 2004) }\end{array}$ \\
\hline $\begin{array}{l}\text { Distribution of dry- } \\
\text { season flows between } \\
\text { farmers, } \\
\text { deforestation, } \\
\text { erosion, surface water } \\
\text { quality }\end{array}$ & $\begin{array}{l}\text { Mae Chaem } \\
\text { catchment, } \\
\text { Thailand }\end{array}$ & $\begin{array}{l}\text { Integrated modeling includes } \\
\text { crop growth, erosion, rainfall- } \\
\text { runoff, household decision, } \\
\text { socio-economic impact } \\
\text { models. }\end{array}$ & $\begin{array}{l}\text { (Letcher et al., } \\
\text { 2006) }\end{array}$ \\
\hline $\begin{array}{l}\text { High agricultural and } \\
\text { urban summer } \\
\text { demands; spatially } \\
\text { heterogenous } \\
\text { demands }\end{array}$ & $\begin{array}{l}\text { Neste basin, } \\
\text { France }\end{array}$ & $\begin{array}{l}\text { Economic optimization driven } \\
\text { simulation (agricultural, } \\
\text { domestic, industrial users), } \\
\text { scenarios: agronomic, } \\
\text { climatic or economic }\end{array}$ & $\begin{array}{l}\text { (Reynaud and } \\
\text { Leenhardt, 2008) }\end{array}$ \\
\hline $\begin{array}{l}\text { Operating cascades } \\
\text { of reservoirs in a } \\
\text { multi-objective, } \\
\text { transboundary } \\
\text { context }\end{array}$ & $\begin{array}{l}\text { Euphrates basin } \\
\text { (Turkey, Syria) }\end{array}$ & $\begin{array}{l}\text { Stochastic programming } \\
\text { to assess statistical } \\
\text { distribution } \\
\text { of marginal water values in } \\
\text { multipurpose multireservoir } \\
\text { system (hydropower, } \\
\text { irrigation) }\end{array}$ & $\begin{array}{l}\text { (Tilmant and } \\
\text { Kelman, 2007; } \\
\text { Tilmant et al., in } \\
\text { press) }\end{array}$ \\
\hline \multicolumn{4}{|c|}{ Water supply, engineering infrastructure and capacity expansion } \\
\hline $\begin{array}{l}\text { Crop and water } \\
\text { supply infrastructure }\end{array}$ & $\begin{array}{l}\text { Tista Project, } \\
\text { East Pakistan }\end{array}$ & $\begin{array}{l}\text { Interactions of surface water- } \\
\text { groundwater system within }\end{array}$ & $\begin{array}{l}\text { (Rogers and } \\
\text { Smith, 1970) }\end{array}$ \\
\hline
\end{tabular}




\begin{tabular}{|c|c|c|c|}
\hline for irrigation & & economic irrigation context & \\
\hline $\begin{array}{l}\text { Water supply; } \\
\text { desalination; sector } \\
\text { allocations }\end{array}$ & $\begin{array}{l}\text { San Luis } \\
\text { Obispo County, } \\
\text { California, } \\
\text { USA }\end{array}$ & Mixed integer programming & $\begin{array}{l}\text { (Armstrong and } \\
\text { Willis, 1977) }\end{array}$ \\
\hline $\begin{array}{l}\text { Operating rule } \\
\text { development }\end{array}$ & $\begin{array}{l}\text { Missouri River, } \\
\text { Columbia } \\
\text { River, USA }\end{array}$ & $\begin{array}{l}\text { Economic-based implicit } \\
\text { stochastic optimization }\end{array}$ & $\begin{array}{l}\text { (Lund and } \\
\text { Ferreira, 1996) }\end{array}$ \\
\hline $\begin{array}{l}\text { Agricultural and } \\
\text { Urban Water supply; } \\
\text { environmental uses }\end{array}$ & $\begin{array}{l}\text { Statewide } \\
\text { California, } \\
\text { USA }\end{array}$ & $\begin{array}{l}\text { Database management; large } \\
\text { diversified system; flexible } \\
\text { policies; infrastructure } \\
\text { expansion }\end{array}$ & $\begin{array}{l}\text { (Draper et al., } \\
\text { 2003; Jenkins et } \\
\text { al., 2004; Null } \\
\text { and Lund, 2006) }\end{array}$ \\
\hline $\begin{array}{l}\text { Competing uses of } \\
\text { infrastructure }\end{array}$ & $\begin{array}{l}\text { Panama Canal } \\
\text { System, } \\
\text { Panama }\end{array}$ & $\begin{array}{l}\text { Trade-off between navigation } \\
\text { and hydropower, capacity } \\
\text { expansion }\end{array}$ & $\begin{array}{l}\text { (Watkins and } \\
\text { Moser, 2006) }\end{array}$ \\
\hline $\begin{array}{l}\text { Probabilistic drought } \\
\text { planning and } \\
\text { operations }\end{array}$ & $\begin{array}{l}\text { East-Bay } \\
\text { Municipal } \\
\text { Utility District, } \\
\text { California, } \\
\text { USA }\end{array}$ & $\begin{array}{l}\text { Linked supply and demand } \\
\text { spreadsheet models }\end{array}$ & $\begin{array}{l}\text { (Jenkins and } \\
\text { Lund, 2000; } \\
\text { Wilchfort and } \\
\text { Lund, 1997) }\end{array}$ \\
\hline $\begin{array}{l}\text { Water conservation } \\
\text { and infrastructure } \\
\text { expansions with } \\
\text { variable water } \\
\text { availability }\end{array}$ & Jordan & $\begin{array}{l}\text { Stochastic mixed integer } \\
\text { programming with non-price } \\
\text { water conservation programs } \\
\text { and infrastructure expansions }\end{array}$ & $\begin{array}{l}\text { (Rosenberg et al, } \\
\text { in press)- }\end{array}$ \\
\hline \multicolumn{4}{|c|}{ Conjunctive use of groundwater and surface water } \\
\hline $\begin{array}{l}\text { Economic } \\
\text { optimization of } \\
\text { conjunctive use }\end{array}$ & $\begin{array}{l}\text { San Joaquin } \\
\text { River Valley, } \\
\text { California, } \\
\text { USA }\end{array}$ & $\begin{array}{l}\text { Maximize expected net } \\
\text { benefits from agricultural } \\
\text { production; stochastic } \\
\text { dynamic programming. }\end{array}$ & (Burt, 1964) \\
\hline $\begin{array}{l}\text { Optimizing } \\
\text { groundwater in an } \\
\text { integrated system }\end{array}$ & Israel & $\begin{array}{l}\text { Economic optimization of } \\
\text { groundwater use with an } \\
\text { integrated system using water } \\
\text { demand curves }\end{array}$ & $\begin{array}{l}\text { (Bear and Levin, } \\
\text { 1966; Bear and } \\
\text { Levin, 1970; } \\
\text { Bear et al., 1964) }\end{array}$ \\
\hline $\begin{array}{l}\text { Stream-aquifer } \\
\text { interaction, spatial } \\
\text { hydrologic effects }\end{array}$ & $\begin{array}{l}\text { Hypothetical } \\
\text { and Platte } \\
\text { Valley, } \\
\text { Colorado, USA }\end{array}$ & $\begin{array}{l}\text { Simulation of conjunctive use } \\
\text { system with distributed } \\
\text { groundwater simulation and } \\
\text { economic model }\end{array}$ & $\begin{array}{l}\text { (Bredehoeft and } \\
\text { Young, 1970; } \\
\text { Young and } \\
\text { Bredehoeft, } \\
\text { 1972) }\end{array}$ \\
\hline $\begin{array}{l}\text { Regional economic } \\
\text { and agricultural } \\
\text { development plan } \\
\text { considering } \\
\text { stochastic supplies }\end{array}$ & $\begin{array}{l}\text { Varamin Plain, } \\
\text { Iran }\end{array}$ & $\begin{array}{l}\text { Combines an agricultural } \\
\text { production optimization } \\
\text { model with a distributed } \\
\text { groundwater simulation } \\
\text { model and a node-link surface } \\
\text { water network }\end{array}$ & $\begin{array}{l}\text { (De Ridder and } \\
\text { Erez, 1977) }\end{array}$ \\
\hline $\begin{array}{l}\text { Agricultural water } \\
\text { allocation }\end{array}$ & $\begin{array}{l}\text { Yolo County, } \\
\text { California, } \\
\text { USA }\end{array}$ & $\begin{array}{l}\text { Integrated groundwater model } \\
\text { using regression equations }\end{array}$ & $\begin{array}{l}\text { (Noel et al., } \\
\text { 1980; Noel and } \\
\text { Howitt, 1982) }\end{array}$ \\
\hline $\begin{array}{l}\text { Efficient conjunctive } \\
\text { use and irrigation } \\
\text { supply system design }\end{array}$ & $\begin{array}{l}\text { Indus Basin, } \\
\text { Pakistan }\end{array}$ & $\begin{array}{l}\text { Simulation of joint effect of } \\
\text { water allocation and } \\
\text { groundwater well tax or } \\
\text { subsidies on economic } \\
\text { efficiency }\end{array}$ & $\begin{array}{l}\text { (O'mara and } \\
\text { Duloy, 1984) }\end{array}$ \\
\hline
\end{tabular}




\begin{tabular}{|c|c|c|c|}
\hline $\begin{array}{l}\text { Groundwater- } \\
\text { irrigated agriculture }\end{array}$ & $\begin{array}{l}\text { Salinas Valley, } \\
\text { California, } \\
\text { USA }\end{array}$ & $\begin{array}{l}\text { Effectiveness of basinwide } \\
\text { groundwater management; } \\
\text { recharge from ephemeral } \\
\text { streams }\end{array}$ & (Reichard, 1987) \\
\hline $\begin{array}{l}\text { Economically } \\
\text { optimal steady-state } \\
\text { pumping }\end{array}$ & $\begin{array}{l}\text { Madera } \\
\text { County, } \\
\text { California, } \\
\text { USA }\end{array}$ & $\begin{array}{l}\text { Approximating the optimal } \\
\text { groundwater pumping for } \\
\text { multi-aquifer stochastic } \\
\text { conjunctive use }\end{array}$ & $\begin{array}{l}\text { (Provencher and } \\
\text { Burt, 1994) }\end{array}$ \\
\hline $\begin{array}{l}\text { Economically } \\
\text { optimal pumping }\end{array}$ & $\begin{array}{l}\text { Kern County, } \\
\text { California, } \\
\text { USA }\end{array}$ & $\begin{array}{l}\text { Artificial recharge of } \\
\text { groundwater }\end{array}$ & $\begin{array}{l}\text { Knapp and } \\
\text { Olson, 1995) }\end{array}$ \\
\hline $\begin{array}{l}\text { Conjunctive use } \\
\text { infrastructure and } \\
\text { water banking }\end{array}$ & $\begin{array}{l}\text { Southern } \\
\text { California, } \\
\text { USA }\end{array}$ & $\begin{array}{l}\text { Optimization of groundwater } \\
\text { conjunctive use and } \\
\text { infrastructure }\end{array}$ & $\begin{array}{l}\text { (Harou and } \\
\text { Lund, in press-a; } \\
\text { Pulido- } \\
\text { Velazquez et al., } \\
\text { 2004) }\end{array}$ \\
\hline $\begin{array}{l}\text { Increasing } \\
\text { agricultural demand, } \\
\text { seawater intrusion }\end{array}$ & \begin{tabular}{|l|} 
Adra River \\
Basin, Spain
\end{tabular} & $\begin{array}{l}\text { embedded multireservoir } \\
\text { method stream-aquifer model, } \\
\text { eigenvalue method } \\
\text { groundwater model, NLP }\end{array}$ & $\begin{array}{l}\text { (Pulido- } \\
\text { Velazquez et al., } \\
\text { 2006) }\end{array}$ \\
\hline $\begin{array}{l}\text { Surface water costs } \\
\text { cause groundwater } \\
\text { overdraft }\end{array}$ & $\begin{array}{l}\text { Tulare Basin, } \\
\text { California, } \\
\text { USA }\end{array}$ & $\begin{array}{l}\text { Economically driven } \\
\text { simulation; quantifies surface } \\
\text { water price effect on } \\
\text { groundwater }\end{array}$ & $\begin{array}{l}\text { (Marques et al., } \\
\text { 2006) }\end{array}$ \\
\hline $\begin{array}{l}\text { Drought, coastal } \\
\text { irrigated agriculture }\end{array}$ & $\begin{array}{l}\text { Yaqui } \\
\text { Valley, Sonora, } \\
\text { Mexico }\end{array}$ & $\begin{array}{l}\text { Embedded agronomic, } \\
\text { distributed groundwater } \\
\text { model; multiobjective } \\
\text { interannual optimization for } \\
\text { sustainability and spill } \\
\text { control; derived conjunctive } \\
\text { use rule }\end{array}$ & $\begin{array}{l}\text { (Schoups et al., } \\
\text { 2006a; Schoups } \\
\text { et al., 2006b) }\end{array}$ \\
\hline \multicolumn{4}{|c|}{ Institutions, water markets and pricing } \\
\hline $\begin{array}{l}\text { Water scarcity due to } \\
\text { lack of infrastructure }\end{array}$ & $\begin{array}{l}\text { California, } \\
\text { USA }\end{array}$ & $\begin{array}{l}\text { Nonlinear spatially } \\
\text { distributed supply and } \\
\text { demand functions, inequality } \\
\text { between number of supply } \\
\text { and demands functions }\end{array}$ & $\begin{array}{l}\text { (Vaux and } \\
\text { Howitt, 1984) }\end{array}$ \\
\hline $\begin{array}{l}\text { Stream-aquifer water } \\
\text { rights issues }\end{array}$ & \begin{tabular}{|l|} 
South Platte \\
River, \\
Colorado, USA \\
\end{tabular} & $\begin{array}{l}\text { Quasi-market maximize } \\
\text { regional income and protect } \\
\text { senior river water rights }\end{array}$ & $\begin{array}{l}\text { (Young et al., } \\
1986)\end{array}$ \\
\hline $\begin{array}{l}\text { Scarce irrigation } \\
\text { supplies; decreased } \\
\text { agricultural } \\
\text { productivity from } \\
\text { salinity }\end{array}$ & \begin{tabular}{|l|} 
Arkansas \\
Valley, \\
Colorado, USA
\end{tabular} & $\begin{array}{l}\text { Market simulation of changes } \\
\text { in surface and groundwater } \\
\text { value due to salinity }\end{array}$ & $\begin{array}{l}\text { (Lefkoff and } \\
\text { Gorelick, 1990a; } \\
\text { Lefkoff and } \\
\text { Gorelick, 1990b) }\end{array}$ \\
\hline $\begin{array}{l}\text { Cost of new urban } \\
\text { supply projects in } \\
\text { southwestern USA }\end{array}$ & \begin{tabular}{|l|} 
Colorado \\
River, USA
\end{tabular} & $\begin{array}{l}\text { Market for consumptive uses, } \\
\text { hydropower production, river } \\
\text { salinity; } 6 \text { institutional } \\
\text { alternatives tested }\end{array}$ & $\begin{array}{l}\text { (Booker and } \\
\text { Young, 1994) }\end{array}$ \\
\hline $\begin{array}{l}\text { Inefficient } \\
\text { institutional } \\
\text { constraints on water } \\
\text { market }\end{array}$ & $\begin{array}{l}\text { Lower Rio } \\
\text { Grande Valley, } \\
\text { Texas, USA }\end{array}$ & $\begin{array}{l}\text { Institutional water market } \\
\text { constraints; optimal portfolios } \\
\text { of rights, options, and leases }\end{array}$ & $\begin{array}{l}\text { (Characklis et } \\
\text { al., 1999; } \\
\text { Characklis et al., } \\
\text { 2006) }\end{array}$ \\
\hline $\begin{array}{l}\text { Water scarcity and } \\
\text { demand for water }\end{array}$ & \begin{tabular}{|l|} 
Southern \\
California,
\end{tabular} & $\begin{array}{l}\text { Economic benefit of flexible } \\
\text { water allocation policies }\end{array}$ & $\begin{array}{l}\text { (Newlin et al., } \\
\text { 2002) }\end{array}$ \\
\hline
\end{tabular}




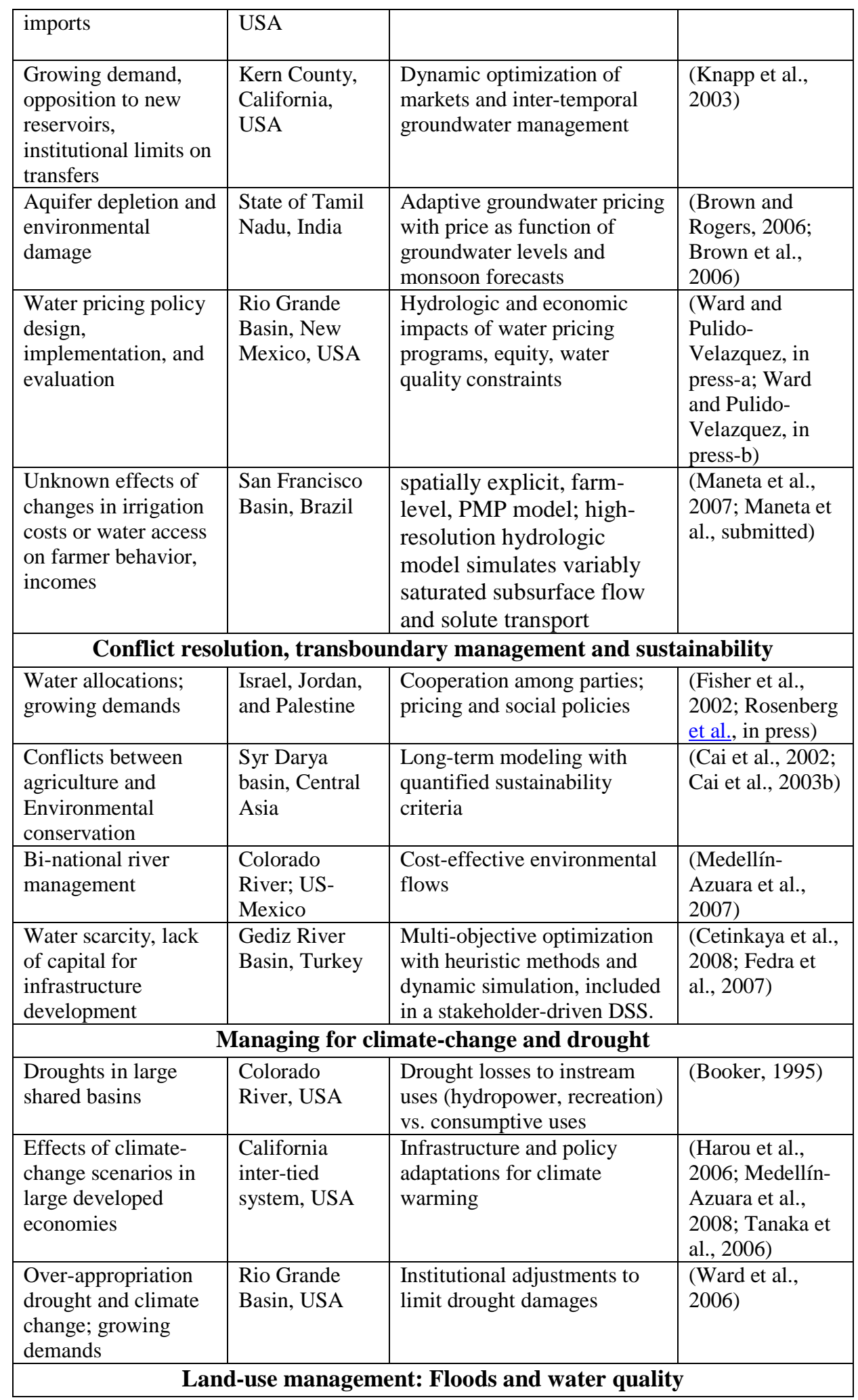




\begin{tabular}{|c|c|c|c|}
\hline $\begin{array}{l}\text { Levee-protected } \\
\text { floodplains; } \\
\text { adaptation to } \\
\text { increasing flood risk }\end{array}$ & $\begin{array}{l}\text { American } \\
\text { River, } \\
\text { California, } \\
\text { USA }\end{array}$ & $\begin{array}{l}\text { Risk-based dynamic } \\
\text { programming; flood } \\
\text { frequency, levee failure } \\
\text { probabilities; hydraulic } \\
\text { simulation; maximizes } \\
\text { difference between land use } \\
\text { value and expected damage }\end{array}$ & (Zhu et al., 2007) \\
\hline $\begin{array}{l}\text { Direct and indirect } \\
\text { economic costs of } \\
\text { floods }\end{array}$ & $\begin{array}{l}\text { Flood prone } \\
\text { areas of the } \\
\text { Netherlands }\end{array}$ & $\begin{array}{l}\text { Flood damages and economy- } \\
\text { wide effects of floods using } \\
\text { spatial hydro-dynamic model }\end{array}$ & $\begin{array}{l}\text { (Jonkman et al., } \\
\text { 2008) }\end{array}$ \\
\hline $\begin{array}{l}\text { European Water } \\
\text { Framework Directive } \\
\text { (WFD) in intensively } \\
\text { cropped river basins }\end{array}$ & $\begin{array}{l}\text { Upper Ems } \\
\text { Basin, } \\
\text { Germany }\end{array}$ & $\begin{array}{l}\text { Spatial DSS links hydrologic, } \\
\text { water quality, and economic } \\
\text { farm models to estimate } \\
\text { economic effects of } \\
\text { alternative agricultural } \\
\text { management options }\end{array}$ & $\begin{array}{l}\text { (Volk et al., } \\
\text { 2008) }\end{array}$ \\
\hline
\end{tabular}

\section{Discussion}

\subsection{Policy and institutional implications}

Hydroeconomic models have policy implications and uses in several areas:

- Infrastructure expansion and operations planning

- Water allocation and markets

- Adaptation pathways (e.g. to climate change)

- Design of institutional policies to achieve environmental, social and economic targets (governance, rights, etc.)

- Economic policy impact analysis, and-øf

- Basis for regulation and law

Most applications of hydroeconomic models, as reviewed above, are for infrastructure planning and operations, water allocation and markets, impact analysis and adaptation. For these, problems for whichhydroeconomic models melding economics and physics in an engineering context and provide unique policy insights.

Several institutional and policy approaches have been proposed to encourage economic efficiency in water management. Idealized water markets achieve the conditions of economic efficiency by encouraging resources to move from lower to higher-valued uses. Various water marketing strategies have been applied (Easter et al., 1998; Lund and Israel, 1995). The introduction of water markets and water banks has made it possible to balance supply and demand and to lessen the effects of severe droughts (Booker et al., 2005; Howitt, 1994). Water markets are also prone to market failures, especially because of the presence of externalities, natural monopolies, and public goods competing with private demands (Young, 1996). Market failures can be corrected, or at least reduced, by introducing appropriate water right and incentives structures (Burness and Quirck, 1979; Griffin and Hsu, 1993; Spulber and Sabbaghi, 1994).

In cases where the supply has to be controlled by government, efficient price is an administrative tool for water demand management. When the price of water reflects 
its true marginal cost, including environmental externalities and other opportunity costs, the resource will be put to its most valuable uses (Rogers et al., 2002). Several international institutions have promoted the principle of full cost recovery (EC, 2000; OECD, 1999) and many countries are now engaged in some form of pricing reform (e.g. Dinar, 2000; OECD, 1999).

In any case, efficient water use fundamentally recognizes water's opportunity cost (Griffin, 2001; 2006). Despite the concept's apparent simplicity, measuring the opportunity cost of water is difficult. In the absence of well-functioning water markets, opportunity cost assessment requires a systems approach and assumptions about real impacts and responses (Briscoe, 1996). This assessment has to be based on an accurately specified system to identify and estimate the value of water for the different users in the system, such as hydroeconomic models.

Hydroeconomic models help investigate changing institutional processes to improve water management. Representing the physics, constraints and objectives of water systems helps water management agencies assess and formulate policies and communicate more clearly with stakeholders.

\subsection{Limitations and challenges}

Some authors have taken a critical look at the usefulness of systems analysis in general for improving water management (e.g. Bredehoeft et al., 1995; Rogers and Fiering, 1986). These authors Bothargue that benefits revealed by optimization solutions are often small due to the relative flatness of objective functions near the optimum and the wide range of nearly optimal solutions. Application of optimization models and their recommendations has remained a challenge (Rogers and Fiering, 1986).

Including economic criteria adds a layer of theory and complexity beyond traditional simulation models that may be difficult or controversial for water managers to accept. To achieve relevance outside of academic and policy circles, hydroeconomic modelers must work with or among real water managers, use and extend established models, and develop and incorporate economic data.

Several difficulties exist with direct use of modeling results. Simplification and aggregation of physical, economic and regulatory processes and data is necessary for timely construction and resolution of regional models. If physical aggregation is coarser than existing simulation models, managers may perceive the hydroeconomic model as too theoretical or insufficiently detailed to support local decision making. Models with simplified process equations also place increased pressure on the reduced parameter set to accurately represent the system. Simplification may contribute to lack of robustness at the local scale; for example a small change in cost on a link in a network model could cause flows to take a dramatically different route. However, at the larger regional scale such local effects tend to balance out leading to generally robust system-wide results in terms of major trends and responses to different scenarios. It is also difficult to make simplified regional models agree with observed data and complex to calibrate these models to historical data (Cai and Wang, 2006; Draper et al., 2003). 
Linearization of non-linear functions or physical process equations is often employed to allow the use of linear programming, which guarantees a global optimum. If nonlinear equations are used, model size is often further reduced for computational reasons.

Another difficulty is moving past the idea that hydroeconomic models necessarily impose market solutions to water resources problems. In fact, hydroeconomic models can be poor tools to simulate actual water markets since individual agent behavior and transaction costs cannot be represented easily (Griffin, 2006 p. 356; Young, 1986). For historical and institutional reasons, most real water resources management schemes are not perfect, inevitably resulting in some inefficiency. Hydroeconomic models can help identify areas where past water management practices are no longer in synch with current resource availability and current social attitudes towards environmental issues such as quality and equity. Using hydroeconomic models helps improve transparency and rationality in natural resource use rather than advocating a particular ideology. Hydroeconomic models help guide (Fisher et al., 2002) policy makers to formulate effective policies; they are not a policy in themselves.

A further difficulty is mathematically representing social, political and environmental objectives in addition to modeling complex processes. Economic objectives have the advantage of summarizing all interests in a single financial metric, reducing a multiobjective problem to a single objective. However, this reduction in solution effort requires additional data collection: estimating economic values of water uses in the study arearegion. Difficult to quantify objectives often include environmental, ecological or social equity. It may be easier to consider some objectives in noneconomic terms, e.g. minimizing differences between releases and the natural flow regime (Tisdell, 2001) to encourage a natural flow regime. Most interests that are not evaluated economically, because of controversy or lack of data, use constraints to reflect social, political or environmental priorities. Not all however; for example decision maker risk aversion is usually not captured by net benefit maximization nor is it straightforward to include as a constraint. Unrealistic levels of risk neutrality can be partially removed by including penalties for failing to achieve allocation targets. When such constraints are small but have a significant effect on allocations they are referred to as persuasion penalties. Alternatively, supplemental terms can be introduced into the objective function, such as terms that minimize the variance between minimal allocations and economic ones. These are stopgap methods and should not prevent the incorporatienng of-nonlinear methods to aversion found in the economics literature(REF?).

The above factors contribute to the limited application of hydroeconomic models for actual water resource planning and management outside of strict academic and policy settings or narrowly focused single-objective hydropower applications.

Cost-benefit analysis remains the most widely used economic technique in the water field. This method helps assess the merit of a particular water infrastructure investment while hydroeconomic models focus on operation and design of systems. Unlike traditional benefit-cost analysis, hydro-economic models provide a way to measure and consider the opportunity costs in water allocation. While benefit-cost analysis provides a single aggregated indicator of economic desirability of a project (i.e., net present value; benefit-cost ration; rate of internal return), the hydro-economic models show the dynamic variation of water values in time and space. As 
management shifts from building new water supply systems to better operating existing ones and adopting demand management and water marketing strategies with increasing water scarcity and water conflicts, this more flexible and detailed form of benefit-cost analysis will become increasingly useful.

As with all environmental modeling, uncertainty and error propagation are especially challenging; most hydroeconomic modeling efforts barely mention them. A pragmatic approach reiterated by Jakeman and Letcher (2003) and Cai (2008) is to use sensitivity analysis to reveal parameters or model components with the greatest effect on results.

\subsection{Current trends and future directions}

Many water management problems are characterized by a pervasive rise in water scarcity, coupled with the-lack of easily developed new supplies, and increasinged levels of drought and extreme events from climate change. In addition, there is a growing priority for environmental flows that require that water be managed in an integrated and sustainable way. These trends mean that by choice or necessity, the more effective management of existing supplies will increasingly be chosen over developing new ones. This focus will increase the relevance and need for practicality of integrated water management techniques such as hydroeconomic modeling.

Although constraints are typically used in lieu of direct economic valuation of environmental benefits, advances in environmental benefits estimation should allow future hydroeconomic models to include more of these benefits in economic objective functions. For decades recreation benefits were considered "intangible", but are now often included.

As optimization solvers improve, optimization models can incorporate more spatial detail and more detailed physical modeling (e.g. spatially distributed groundwater flow, stream-aquifer interaction, routed surface flows). Incorporatingen of water quality processes will be especially important (Lefkoff and Gorelick, 1990b).

Most hydroeconomic models are custom-built, often using commercial optimization software. With economic criteria gaining acceptance for representing indicating system performance, hydroeconomic models will continue to appear in decision support systems (DSS) (section 3.3) or integrated assessments (Letcher et al., 2006). This trend will accentuate as optimization capabilities are more frequently available in DSS. Calibration methods (e.g. Cai and Wang, 2006; Howitt, 1998) for optimization may also be integrated into future practical applications.

The ability to analyze economic impacts of different system designs or management policies is significant. Although there is an inevitable gap between modeling research and its application in decision-making, this gap should decrease as hydroeconomic models are included into collaborative planning processes such as shared vision planning (Palmer et al., 1999; Stephenson et al., 2007) or integrated assessments (Parker et al., 2002). Synthesis of what inherently is a multi-objective problem into a single economic objective is both a strength and weakness of the approach. Solutions proposed by hydroeconomic models will have the most credibility if they are 
advanced with broader perspectives that consider the problem from many angles. Hydroeconomic models should be useful in shared-vision planning and integrated assessments by providing useful information to negotiators. Making the economic impacts of any proposed water policy or management scheme explicit will increase transparency and empower those who take part in the decision processes.

\section{Conclusions}

Hydro-economic models represent hydrologic engineered systems while explicitly considering the economic nature of water demands and costs. Beyond minimizing costs or maximizing profits, they provide a framework to consider the value of water services in planning and operation. A variety of techniques exist to estimate the economic value of water uses. Managing for water value allows the water system to be dynamic and quickly respond to economic, social, and environmental changes.

Numerous efforts dating back at least 40 years have integrated economic and engineering realities in mathematical models to recommend improvements in the design, operation, and reoperation of water systems. Applications have spanned the globe and addressed numerous problems including: on- and off-stream intersectoral allocations, water supply, infrastructure capacity expansions, conjunctive use of surface and groundwater, institutions, markets, pricing, conflict resolution, transboundary management, climate change, drought response, flood response, and water quality.

Many choices confront the hydroeconomic model builder; foremost is what questions is the model being built to address? Subsequently, the modeler must choose whether to simulate or optimize, include environmental values and benefits in the objective function, adopt a modular or holistic design, and how to represent time in the model formulation.

Until now, hydroeconomic modeling has been practiced in academic and policy circles with limited implementation of study recommendations by water managers, operators, and practitioners. Hydroeconomic modelers can improve the impact of their work by collaborating with practitioners and extending existing (and trusted) operations models to include hydroeconomic components.

In the future, we foresee increased use of hydroeconomic models to study water transfers, re-operations, and water-use efficiency rather than new supply or infrastructure developments. Also, to includinge environmental and recreational values in the economic objective function, more spatial disaggregation, and more attention to water quality and uncertainties. Finally, particularly promising is use of hydroeconomic models within collaborative conflict resolution approaches such as shared vision planning.

Combining engineering, economics and hydrologic science, a hydroeconomic approach is well positioned to help foster integrated water resources management (IWRM). Hydroeconomic models can help guide policy making and reveal where innovative and dynamic policies can replace outdated arrangements. As water scarcity caused by increased demand and lack of new supplies increases worldwide, resource managers will increasingly turn to tools which reveal with transparency 
where greater efficiency in water use can be attained. Hydroeconomic modeling can help water managers more effectively steward water resources and provide the best possible water supply and environmental quality to their constituents. 


\section{References}

Alcubilla, R.G. and Lund, J.R., 2006. Derived Willingness-to-Pay for Household Water Use with Price and Probabilistic Supply. Journal of Water Resources Planning and Management, 132(6): 424-433.

Andreu-Álvarez, J., Pulido-Velázquez, M. and Collazos, G., 2005. Methodology and tools for integrated assessment of resource and environmental requirements costs, Second international workshop on implementing economic analysis in the water framework directive, Paris, France.

Andreu, J., Capilla, J. and Sanchis, E., 1996. AQUATOOL, a generalized decisionsupport system for water-resources planning and operational management. Journal of Hydrology, 177(3-4): 269-291.

Argent, R.M. et al., 2006. Comparing modelling frameworks - A workshop approach. Environmental Modelling \& Software, 21(7): 895-910.

Armstrong, R.D. and Willis, C.E., 1977. Simultaneous Investment and Allocation Decisions Applied to Water Planning. Management Science, 23(10): 10801088.

Bear, J. and Levin, O., 1966. Optimal utilization of an aquifer as an element of a water-resources system. P.N. 5/66, Hydraulic Lab., Technion - Israel Inst. of Technology, Haifa.

Bear, J. and Levin, O., 1967. The optimal yield of an aquifer, Haifa Symposium. International Association of Hydrological Sciences, Haifa, pp. 401-412.

Bear, J. and Levin, O., 1970. Optimal utilization of an aquifer as an element of a water-resource system: Research period 1967-68. In: O. Levin (Editor), Selected Works in Operations Research and Hydraulics. Israel Institute of Technology, Haifa, pp. 64-279.

Bear, J., Levin, O. and Buras, N., 1964. Optimal Utilization of Aquifers as Elements of Water-resources Systems, Progress Report No. 1: Basic Concepts and Program of Research, Technion - Israel Institute of Technology, Hydraulic Laboratory, Haifa.

Booker, J.F., 1995. Hydrologic and Economic-Impacts of Drought under Alternative Policy Responses. Water Resources Bulletin, 31(5): 889-906.

Booker, J.F., Michelsen, A.M. and Ward, F.A., 2005. Economic impact of alternative policy responses to prolonged and severe drought in the Rio Grande Basin. Water Resources Research, 41(2).

Booker, J.F. and Young, R.A., 1994. Modeling Intrastate and Interstate Markets for Colorado River Water-Resources. Journal of Environmental Economics and Management, 26(1): 66-87.

Braat, L.C. and Lierop, W.F.J. (Editors), 1987. Integrated economic-Ecological modeling. Integrated economic ecological modeling.

Braden, J.B., 2000. Value of valuation: Introduction. Journal of Water Resources Planning and Management-Asce, 126(6): 336-338.

Bredehoeft, J.D., Reichard, E.G. and Gorelick, S.M., 1995. If It Works, Don't Fix It: Benefits from Regional Groundwater Management. In: A.I. El-Kadi (Editor), Groundwater Models for Resources Analysis and Management. CRC, Boca Raton, London, Tokyo, pp. 103-124.

Bredehoeft, J.D. and Young, R.A., 1970. The Temporal Allocation of Ground Water A Simulation Approach. Water Resources Research, 6(1): 3-21.

Briscoe, J., 1996. Water as an Economic Good. The Idea and What It Means in Practice, Proceedings of the World Congress of the International Commission on Irrigation and Drainage (ICID). ICID, Cairo, Egypt. 
Brouwer, R., 2000. Environmental value transfer: state of the art and future prospects. Ecological Economics, 32(1): 137-152.

Brouwer, R. and Hofkes, M., 2008. Integrated hydro-economic modelling: Approaches, key issues and future research directions. Ecological Economics, 66(1): 16-22.

Brown, C. and Rogers, P., 2006. Effect of forecast-based pricing on irrigated agriculture: A simulation. Journal of Water Resources Planning and Management-Asce, 132(6): 403-413.

Brown, C., Rogers, P. and Lall, U., 2006. Demand management of groundwater with monsoon forecasting. Agricultural Systems, 90(1-3): 293-311.

Brown, T.C., Diaz, G.E. and Sveinsson, O.G.B., 2002. Planning Water Allocation In River Basins Aquarius: A System's Approach, Proceedings of 2nd Federal Interagency Hydrologic Modeling Conference, Subcommittee on Hydrology of the Advisory Committee on Water Information, July 28-August 1, 2002,, Las Vegas, NV.

Brown, T.C., Harding, B.L. and Payton, E.A., 1990. Marginal Economic Value of Streamflow - a Case-Study for the Colorado River Basin. Water Resources Research, 26(12): 2845-2859.

Burness, H.S. and Quirck, J.P., 1979. Appropriative water rights and the efficient allocation of resources. American Economics Review, 69(1): 25-37.

Burt, O.R., 1964. Optimal resource use over time with an application to ground water. Management Science, 11(1): 80-93.

Cai, X. and Wang, D., 2006. Calibrating Holistic Water Resources--Economic Models. Journal of Water Resources Planning and Management, 132(6): 414423.

Cai, X.M., 2008. Implementation of holistic water resources-economic optimization models for river basin management - Reflective experiences. Environmental Modelling \& Software, 23(1): 2-18.

Cai, X.M., McKinney, D.C. and Lasdon, L.S., 2002. A framework for sustainability analysis in water resources management and application to the Syr Darya Basin. Water Resources Research, 38(6).

Cai, X.M., McKinney, D.C. and Lasdon, L.S., 2003a. Integrated hydrologicagronomic-economic model for river basin management. Journal of Water Resources Planning and Management-Asce, 129(1): 4-17.

Cai, X.M., McKinney, D.C. and Rosegrant, M.W., 2003b. Sustainability analysis for irrigation water management in the Aral Sea region. Agricultural Systems, 76(3): 1043-1066.

Cai, X.M., Rosegrant, M.W. and Ringler, C., 2003c. Physical and economic efficiency of water use in the river basin: Implications for efficient water management. Water Resources Research, 39(1).

Cardwell, H.E., Cole, R.A., Cartwright, L.A. and Martin, L.A., 2006. Integrated water resources management: definitions and conceptual musings. Journal of Contemporary Water Research \& Education (35): 8-18.

Cetinkaya, C.P., Fistikoglu, O., Fedra, K. and Harmancioglu, N.B., 2008. Optimization methods applied for sustainable management of water-scarce basins. Journal of Hydroinformatics, 10: 69-95.

Characklis, G.W., Griffin, R.C. and Bedient, P.B., 1999. Improving the ability of a water market to efficiently manage drought. Water Resources Research, 35(3): 823-831. 
Characklis, G.W., Kirsch, B.R., Ramsey, J., Dillard, K.E.M. and Kelley, C.T., 2006. Developing portfolios of water supply transfers. Water Resources Research, 42(5): 14.

Colby, B.G., 1990. Enhancing Instream Flow Benefits in an Era of Water Marketing. Water Resources Research, 26(6): 1113-1120.

Conrad, J.M. and Clark, C.W., 1987. Natural resource economics. Cambridge University Press, Cambridge.

CUWA, 1991. Cost of industrial water shortages, California Urban Water Agencies, Prepared by Spectrum Economics Inc., San Francisco, Calif.

De Ridder, N.A. and Erez, A., 1977. Optimum use of water resources, Publication 21. Publication 21, International Institute for Land Reclamation and Improvement/lLRI, Wageningen, The Netherlands.

Diaz, G.E. and Brown, T.C., 1997. Aquarius: an object-oriented model for efficient allocation of water in river basins. In: J.J. Warwick (Editor), Symposium Water Resources Education, Training, and Practice: Opportunities for the Next Century, June 29-July 3, 1997, Keystone, CO., pp. 835-844.

Diaz, G.E., Brown, T.C. and Morel-Seytoux, H.J. (Editors), 1992. The marginal economic value of streamflows: a systems approach. Proceedings of American Geophysical Union Twelfth Annual Hydrology Days, Proceedings of American Geophysical Union Twelfth Annual Hydrology Days. Hydrology Days Publications, Atherton, California, 352-367 pp.

Diaz, G.E., Brown, T.C. and Sveinsson, O.G.B., 2000. Aquarius: A modeling system for river basin water allocation. General Technical Report RM-GTR-299. U.S. Department of Agriculture, Forest Service, Rocky Mountain Forest and Range Experiment Station, Fort Collins, CO.

Dinar, A., 2000. Political Economy of Water Pricing Reforms. In: A. Dinar (Editor), The Political Economy of Water Pricing Reforms. Oxford University Press, New York.

Draper, A.J., Jenkins, M.W., Kirby, K.W., Lund, J.R. and Howitt, R.E., 2003. Economic-engineering optimization for California water management. Journal of Water Resources Planning and Management-Asce, 129(3): 155-164.

Draper, A.J. et al., 2004. CalSim: Generalized model for reservoir system analysis. Journal of Water Resources Planning and Management-Asce, 130(6): 480489.

Dupuit, J., 1844. De la mesure de l'utilité des travaux publics. Annales des Ponts et Chaussées, Memoirs et Documents, 2nd ser.(8(2)): 332-375.

Easter, K.W., Rosegrant, M.W. and Dinar, A. (Editors), 1998. Markets for water. Potential and performance. Springer, $352 \mathrm{pp}$.

EC, 2000. Directive 2000/60/Ec of the European Parliament and of the Council, of 23 October 2000, Establishing a Framework for Community Action in the Field of Water Policy, Official Journal of the European Economics. European Commission.

Ekelund, R.B. and Hebert, R.F., 1999. Secret origins of modern microeconomics: Dupuit and the engineers. University of Chicago Press, Chicago.

Espey, M., Espey, J. and Shaw, W.D., 1997. Price elasticity of residential demand for water: A meta-analysis. Water Resources Research, 33(6): 1369-1374.

Evans, E.M. et al., 2003. Achieving efficiency and equity in irrigation management: an optimization model of the El Angel watershed, Carchi, Ecuador. Agricultural Systems, 77(1): 1-22. 
Fedra, K., Kubat, M. and Zuvela-Aloise, M., 2007. Water Resources Management: Economic Valuation and Participatory Multi-Criteria Optimization, Second IASTED International Conference. IASTED, Honolulu, Hawaii, USA.

Fisher, F.M. et al., 2002. Optimal water management and conflict resolution: The Middle East Water Project. Water Resources Research, 38(11).

Fisher, F.M., Huber-Lee, A., Amir, I. and Haddadin, M.J., 2005. Liquid Assets: An Economic Approach for Water Management and Conflict Resolution in the Middle East and Beyond. Resources for the Future, 242 pp.

Freeman, A.M., 2003. The measurement of environmental and resource values theory and methods. Resources for the Future, Washington, DC.

Gibbons, D.C., 1986. The economic value of water. Resources for the Future, Washington D.C.

Gisser, M. and Mercado, A., 1972. Integration of the agricultural demand function for water and the hydrologic model of the pecos basin. Water Resources Research, 8(6): 1373-1384.

Gisser, M. and Mercado, A., 1973. Economic Aspects of Ground Water Resources and Replacement Flows in Semiarid Agricultural Areas. American Journal of Agricultural Economics, 55(3): 461-466.

Global Water Partnership, 2000. Integrated Water Resources Management, Global Water Partnership TAC Background Paper 4, Stockholm, Sweden.

Griffin, R.C., 1990. Valuing urban water acquisitions. Water Resour. Bull., 26(2): 219-225.

Griffin, R.C., 1998. The fundamental principles of cost-benefit analysis. Water Resources Research, 34(8): 2063-2071.

Griffin, R.C., 2001. Effective water pricing. Journal of the American Water Resources Association, 37(5): 1335-1347.

Griffin, R.C., 2006. Water Resource Economics - The Analysis of Scarcity, Policies and Projects. MIT Press, Cambridge, Massachusetts.

Griffin, R.C. and Chang, C., 1991. Seasonality in Community Water Demand. Western Journal of Agricultural Economics, 16(2): 207-217.

Griffin, R.C. and Hsu, S.-H., 1993. The Potential for Water Market Efficiency When Instream Flows Have Value. American Journal of Agricultural Economics, 75(May 1993): 292-303.

Griffin, R.C. and Mjelde, J.W., 2000. Valuing water supply reliability. American Journal of Agricultural Economics, 82(2): 414-426.

Hanemann, W.M., 1998. Determinants of urban water use. In: D.D. Baumann, J. Boland and W.M. Hanemann (Editors), Urban Water Demand Management and Planning. McGraw-Hill, NY, pp. 31-75.

Harou, J. et al., 2006. Extreme Drought and Water Supply Management in California. In: G. Randall (Editor), ASCE World Environmental and Water Resources Institute Congress 2006. ASCE, Omaha, Nebraska, pp. 278.

Harou, J.J. and Lund, J.R., in press-a. Groundwater overdraft in hydrologic-economic systems. Hydrogeology Journal.

Harou, J.J. and Lund, J.R., in press-b. Representing Groundwater in Water Management Models - Applications to California, PIER Report: California Energy Commission.

Hayek, F.A., 1950. The counter-revolution of science: Studies on the abuse of reason. Liberty Fund Publishers, Indianapolis.

Heinz, I., Pulido-Velazquez, M., Lund, J.R. and Andreu, J., 2007. Hydro-economic modeling in river basin management: Implications and applications for the 
European Water Framework Directive. Water Resources Management, 21(7): 1103-1125.

Howitt, R.E., 1994. Empirical-Analysis of Water Market Institutions - the 1991

California Water Market. Resource and Energy Economics, 16(4): 357-371.

Howitt, R.E., 1995. Positive Mathematical-Programming. American Journal of Agricultural Economics, 77(2): 329-342.

Howitt, R.E., 1998. Self-Calibrating Network Flow Models. Unpublished working paper.

Howitt, R.E., Ward, K.B. and Msangi, S.M., 2001. Appendix A: Statewide Water and Agricultural Production Model, . In: M.W. Jenkins et al. (Editors), Improving California Water Management: Optimizing Value and Flexibility, Center for Environmental and Water Resources Engineering, University of California, Davis, CA.

Jakeman, A.J. and Letcher, R.A., 2003. Integrated assessment and modelling: features, principles and examples for catchment management. Environmental Modelling \& Software, 18(6): 491-501.

Jakeman, A.J., Letcher, R.A. and Norton, J.P., 2006. Ten iterative steps in development and evaluation of environmental models. Environmental Modelling \& Software, 21(5): 602-614.

Jenkins, M.W., Howitt, R. E., Lund, J.R., Draper, A.J., Tanaka, S.K., Ritzema, R.S., Marques, G.F., Msangi, S.M., Newlin, B.D., Van Lienden, B.J., Davis, M.D., and Ward, K.B, 2001. Improving California Water Management: Optimizing Value and Flexibility. Report No. 01-1, Center for Environmental and Water Resources Engineering, University of California.

Jenkins, M.W. and Lund, J.R., 2000. Integrating yield and shortage management under multiple uncertainties. Journal of Water Resources Planning and Management-Asce, 126(5): 288-297.

Jenkins, M.W., Lund, J.R. and Howitt, R.E., 2003. Using economic loss functions to value urban water scarcity in California. Journal American Water Works Association, 95(2): 58-+.

Jenkins, M.W. et al., 2004. Optimization of California's water supply system: Results and insights. Journal of Water Resources Planning and Management-Asce, 130(4): 271-280.

Jonkman, S.N., Bockarjova, M., Kok, M. and Bernardini, P., 2008. Integrated hydrodynamic and economic modelling of flood damage in the Netherlands. Ecological Economics, 66(1): 77-90.

Kindler, J. and Russell, C.S., 1984. Modeling Water Demands. Academic Press Inc.

Knapp, K.C. and Olson, L.J., 1995. The Economics of Conjunctive GroundwaterManagement with Stochastic Surface Supplies. Journal of Environmental Economics and Management, 28(3): 340-356.

Knapp, K.C., Weinberg, M., Howitt, R. and Posnikoff, J.F., 2003. Water transfers, agriculture, and groundwater management: a dynamic economic analysis. Journal of Environmental Management, 67(4): 291-301.

Labadie, J.W., 2004. Optimal operation of multireservoir systems: State-of-the-art review. Journal of Water Resources Planning and Management-Asce, 130(2): 93-111.

Labadie, J.W. and Baldo, M.L., 2000. MODSIM: Decision Support System for River Basin Management: Documentation and User Manual, Dept. of Civil Engrg., Colo.State Univ., Ft. Collins, Colo.

Langins, J., 2004. Conserving the enlightenment: French military engineering from Vauban to the revolution. MIT Press, Cambridge, Mass. 
Lefkoff, L.J. and Gorelick, S.M., 1990a. Benefits of an Irrigation Water Rental Market in a Saline Stream-Aquifer System. Water Resources Research, 26(7): 1371-1381.

Lefkoff, L.J. and Gorelick, S.M., 1990b. Simulating Physical Processes and Economic-Behavior in Saline, Irrigated Agriculture - Model Development. Water Resources Research, 26(7): 1359-1369.

Letcher, R., 2005. Implementation Of A Water Allocation Decision Support System In The Namoi And Gwydir Valleys. In: A. Zerger and R.M. Argent (Editors), MODSIM 2005 International Congress on Modelling and Simulation. Modelling and Simulation Society of Australia and New Zealand, Canberra, Australia.

Letcher, R.A., Croke, B.F.W., Jakeman, A.J. and Merritt, W.S., 2006. An integrated modelling toolbox for water resources assessment and management in highland catchments: Model description. Agricultural Systems, 89(1): 106131.

Letcher, R.A., Jakeman, A.J. and Croke, B.F.W., 2004. Model development for integrated assessment of water allocation options. Water Resources Research, 40(5).

Loucks, D.P., Stedinger, J.R. and Haith, D.A., 1981. Water resources systems planning and analysis. Prentice-Hal, Englewood Cliffs, N.J.

Lund, J.R., 1995. Derived Estimation of Willingness-to-Pay to Avoid Probabilistic Shortage. Water Resources Research, 31(5): 1367-1372.

Lund, J.R., Cai, X. and Characklis, G.W., 2006. Economic Engineering of Environmental and Water Resource Systems. Journal of Water Resources Planning and Management, 132(6): 399-402.

Lund, J.R. and Ferreira, I., 1996. Operating rule optimization for Missouri River reservoir system. Journal of Water Resources Planning and ManagementAsce, 122(4): 287-295.

Lund, J.R. and Israel, M., 1995. Water Transfers in Water-Resource Systems. Journal of Water Resources Planning and Management-Asce, 121(2): 193-204.

Maass, A. et al., 1962. Design of Water-Resources Systems. Harvard University Press, Cambridge, Massachusetts.

Maneta, M.P. et al., 2007. A Detailed Hydro-Economic Model for Assessing the Effects of Surface Water and Groundwater Policies: A Demonstration Model from Brazil, American Agricultural Economics Association Annual Meeting. American Agricultural Economics Association, Portland, Oregon, .

Maneta, M.P. et al., submitted. A spatially distributed hydro-economic model to assess the economic impact of water policies on rural poverty. Water Resources Research.

Mariño, M.A. and Simonovic, S.P. (Editors), 2001. Integrated Water Resources Management. Publ. no. 272. IAHS Press.

Marques, G.F. et al., 2006. Economically Driven Simulation of Regional Water Systems: Friant-Kern, California. Journal of Water Resources Planning and Management, 132(6): 468-479.

Martin, W. and Thomas, F.T., 1986. Policy relevance in urban residential water demand. Water Resour. Res., 22(13): 1735-1741.

McCarl, B.A., Dillon, C.R., Keplinger, K.O. and Williams, R.L., 1999. Limiting pumping from the Edwards Aquifer: An economic investigation of proposals, water markets, and spring flow guarantees. Water Resources Research, 35(4): 1257-1268. 
McKinney, D., Cai, X., Rosegrant, M.W., Ringler, C. and Scott, C.A., 1999.

Modeling Water Resources Management at the Basin Level: Review and Future Directions. SWIM Paper 6, International Water Management Institute, Colombo.

Medellín-Azuara, J. et al., 2008. Adaptability and Adaptations of California’s Water Supply System to Dry Climate Warming. Climatic Change, 87(Suppl 1): S75S90.

Medellin-Azuara, J., Lund, J.R. and Howitt, R., 2007. Water Supply Analysis for Restoring the Colorado River Delta, Mexico. Journal of water Resources Planning and Management, 133(5).

Medellín-Azuara, J., Lund, J.R. and Howitt, R.E., 2007. Water Supply Analysis for Restoring the Colorado River Delta, México. Journal of Water Resources Planning and Management, 133(4).

Moore, M.R., Gollehon, N.R. and Carey, M.B., 1994. Multicrop production decisions in western irrigated agriculture: the role of water price. Amer. J. Ag. Econ., 76: 859-874.

Mukherjee, N., 1996. Water and Land in South Africa: Economywide Impacts of Reform - A Case Study for the Olifants River. Trade and Macroeconomics Division (TMD) Discussion Paper No. 12, International Food Policy Research Institute., Washington, D.C.

Newlin, B.D., Jenkins, M.W., Lund, J.R. and Howitt, R.E., 2002. Southern California water markets: Potential and limitations. Journal of Water Resources Planning and Management-Asce, 128(1): 21-32.

Noel, J.E., Gardner, B.D. and Moore, C.V., 1980. Optimal Regional Conjunctive Water Management. American Journal of Agricultural Economics, 62(3): 489498.

Noel, J.E. and Howitt, R.E., 1982. Conjunctive Multibasin Management - an OptimalControl Approach. Water Resources Research, 18(4): 753-763.

Null, S.E. and Lund, J.R., 2006. Reassembling Hetch Hetchy: Water supply without O'Shaughnessy Dam. Journal of the American Water Resources Association, 42(2): 395-408.

O'mara, G.T. and Duloy, J.H., 1984. Modeling Efficient Water Allocation in a Conjunctive Use Regime - the Indus Basin of Pakistan. Water Resources Research, 20(11): 1489-1498.

OECD, 1999. The Price of Water: Trends in O.E.C.D. Countries, Organization for Economic Cooperation and Development, Paris, France.

Palmer, R.N., Werick, W.J., MacEwan, A. and Wood, A.W., 1999. Modeling water resources opportunities, challenges and trade-offs: the use of Shared Vision Modeling for negotiation and conflict resolution, ASCE's 26th Annual Conference on Water Resources Planning and Management, Tempe, AZ. ASCE, Tempe, AZ

Parker, P. et al., 2002. Progress in integrated assessment and modelling. Environmental Modelling \& Software, 17(3): 209-217.

Provencher, B. and Burt, O., 1994. Approximating the Optimal Groundwater Pumping Policy in a Multiaquifer Stochastic Conjunctive Use Setting. Water Resources Research, 30(3): 833-843.

Pulido-Velazquez, M., Andreu, J., Heinz, I. and Lund, J.R. (Editors), in press. HydroEconomic Modeling And Tools For Implementation Of The European Water Framework Directive. International Workshop On Hydro-Economic Modeling 
And Tools For Implementation Of The European Water Framework Directive. Springer, Valencia, Spain.

Pulido-Velazquez, M., Andreu, J. and Sahuquillo, A., 2006. Economic Optimization of Conjunctive Use of Surface Water and Groundwater at the Basin Scale. Journal of Water Resources Planning and Management, 132(6): 454-467.

Pulido-Velazquez, M., Jenkins, M.W. and Lund, J.R., 2004. Economic values for conjunctive use and water banking in southern California. Water Resources Research, 40(3).

Randall, A., 1981. Property entitlements and pricing policies for a maturing water economy. The Australian Journal of Agricultural Economics, 25: 195-220.

Reichard, E.G., 1987. Hydrologic Influences on the Potential Benefits of Basinwide Groundwater-Management. Water Resources Research, 23(1): 77-91.

Renzetti, S., 2002. The economics of water demands. Kluwer Academic Publishers, $191 \mathrm{pp}$.

Reynaud, A. and Leenhardt, D., 2008. MoGIRE: A model for integrated water management, Proceedings of the iEMSs Fourth Biennial Meeting: International Congress on Environmental Modelling and Software. International Environmental Modelling and Software Society, Barcelona, Catalonia, pp. 576-583.

Rogers, P., Silva, R.d. and Bhatia, R., 2002. Water Is an Economic Good. How to Use Prices to Promote Equity, Efficiency, and Sustainability. . Water Policy (4):117, 4(1): 1-17.

Rogers, P. and Smith, D.V., 1970. Integrated Use of Ground and Surface Water in Irrigation Project Planning. American Journal of Agricultural Economics, 52(1): 13-\&.

Rogers, P.P. and Fiering, M.B., 1986. Use of Systems-Analysis in Water Management. Water Resources Research, 22(9): S146-S158.

Rosegrant, M.W. et al., 2000. Integrated economic-hydrologic water modeling at the basin scale: the Maipo river basin. Agricultural Economics, 24(1): 33-46.

Rosenberg, D.E., in press. Regional Water Management with Water Use Efficiency, Infrastructure Expansions, and Source Variability.

Rosenberg, D.E., Tarawneh, T., Abdel-Khaleq, R. and Lund, J.R., 2007. Modeling integrated water user decisions in intermittent supply systems. Water Resour. Res., 43.

Scheierling, S.M., Loomis, J.B. and Young, R.A., 2006. Irrigation water demand: A meta-analysis of price elasticities. Water Resources Research, 42(1).

Schoups, G., Addams, C.L., Minjares, J.L. and Gorelick, S.M., 2006a. Reliable conjunctive use rules for sustainable irrigated agriculture and reservoir spill control. Water Resources Research, 42(12).

Schoups, G., Addams, C.L., Minjares, J.L. and Gorelick, S.M., 2006b. Sustainable conjunctive water management in irrigated agriculture: Model formulation and application to the Yaqui Valley, Mexico. Water Resources Research, 42(10).

Shabman, L. and Stephenson, K., 2000. Environmental valuation and its economic critics. Journal of Water Resources Planning and Management-ASCE, 126(6): 382-388.

Spulber, N. and Sabbaghi, A., 1994. Economics of water resources: from regulation to privatization. Kluwer Academic Publishers.

Stephenson, K., Shabman, L., Langsdale, S. and Cardwell, H., 2007. Computer Aided Dispute Resolution: Proceedings from the CADRe Workshop, IWR Report 07-R-6, USACE IWR. 
Tanaka, S.K. et al., 2006. Climate warming and water management adaptation for California. Climatic Change, 76(3-4): 361-387.

Tilmant, A. and Kelman, R., 2007. A stochastic approach to analyze trade-offs and risks associated with large-scale water resources systems. Water Resources Research, 43(6): 11.

Tilmant, A., Pinte, D. and Goor, Q., in press. Assessing marginal water values in multipurpose multireservoir systems via stochastic programming. Water Resources Research.

Tisdell, J.G., 2001. The environmental impact of water markets: An Australian casestudy. Journal of Environmental Management, 62(1): 113-120.

Todini, E., Shumann, A. and Assimacopoulos, D., 2006. The WaterStrategyMan Decision Support System. In: P. Koundouri, K. Karousakis, D.

Assimacopoulos, P. Jeffrey and M. Lange (Editors), Water Management in Arid and Semi-arid Regions: Interdisciplinary Perspectives. Edward-Elgar Publishing Ltd., Cheltenham, UK.

Tsur, Y., Roe, T., Dinar, A. and Doukkali, M., 2004. Pricing Irrigation Water: Principles and Cases from Developing Countries. Resources for the Future, Washington, D.C.

U.N., 1992. The Dublin Statement on Water and Sustainable Development. United Nations International Conference on Water and the Environment.

Vaux, H.J. and Howitt, R.E., 1984. Managing Water Scarcity - an Evaluation of Interregional Transfers. Water Resources Research, 20(7): 785-792.

Volk, M. et al., 2008. Integrated ecological-economic modelling of water pollution abatement management options in the Upper Ems River Basin. Ecological Economics, 66(1): 66-76.

Ward, F.A., Booker, J.F. and Michelsen, A.M., 2006. Integrated economic, hydrologic, and institutional analysis of policy responses to mitigate drought impacts in Rio Grande Basin. Journal of Water Resources Planning and Management-Asce, 132(6): 488-502.

Ward, F.A. and Lynch, T.P., 1996. Integrated river basin optimization: Modeling economic and hydrologic interdependence. Water Resources Bulletin, 32(6): 1127-1138.

Ward, F.A. and Lynch, T.P., 1997. Is dominant use management compatible with basin-wide economic efficiency? Water Resources Research, 33(5): 11651170.

Ward, F.A. and Pulido-Velazquez, M., in press-a. Efficiency, equity, and sustainability in a water quantity-quality optimization model in the Rio Grande basin. Ecological Economics, In Press, Corrected Proof.

Ward, F.A. and Pulido-Velazquez, M., in press-b. Incentive pricing and cost recovery at the basin scale. Journal of Environmental Management, In Press, Corrected Proof.

Watkins, J.D.W. and Moser, D.A., 2006. Economic-Based Optimization of Panama Canal System Operations. Journal of Water Resources Planning and Management, 132(6): 503-512.

Wilchfort, G. and Lund, J.R., 1997. Shortage management modeling for urban water supply systems. Journal of Water Resources Planning and Management-Asce, 123(4): 250-258.

Young, R.A., 1986. Why Are There So Few Transactions among Water Users. American Journal of Agricultural Economics, 68(5): 1143-1151. 
Young, R.A., 1996. Measuring Economics Benefits for Water Investments and Policies, World Bank Technical Paper No. 338, World Bank, Washington DC, USA.

Young, R.A., 2005a. Determining the economic value of water : concepts and methods. Resources for the Future, Washington, D.C.

Young, R.A., 2005b. Determining the economic value of water: concepts and methods. Resources for the Future, Washington D.C.

Young, R.A. and Bredehoeft, J.D., 1972. Digital-Computer Simulation for Solving Management Problems of Conjunctive Groundwater and Surface Water Systems. Water Resources Research, 8(3): 533-548.

Young, R.A., Daubert, J.T. and Morelseytoux, H.J., 1986. Evaluating Institutional Alternatives for Managing an Interrelated Stream-Aquifer System. American Journal of Agricultural Economics, 68(4): 787-797.

Zhu, T.J., Lund, J.R., Jenkins, M.W., Marques, G.F. and Ritzema, R.S., 2007. Climate change, urbanization, and optimal long-term floodplain protection. Water Resources Research, 43(6). 